\title{
The Paleoproterozoic Waterberg Group, South Africa: Provenance and its relation to the timing of the Limpopo orogeny
}

\author{
P.L. Corcoran ${ }^{a, *}$, A.J. Bumby ${ }^{\text {b }}$, D.W. Davis ${ }^{c}$ \\ a Department of Earth Sciences, Western University, London, Ontario, Canada N6A 5B7 \\ ${ }^{b}$ Department of Geology, University of Pretoria, Pretoria 0002, South Africa \\ c Department of Geology, University of Toronto, Toronto, Ontario, Canada M5S 3B1
}

Keywords:

Limpopo Belt

Waterberg Group

Palaeoproterozoic

Geochemistry

Detrital zircon U-Pb geochronology

Provenance

\section{A B S T R A C T}

Four Paleoproterozoic formations of the Waterberg Group in South Africa are composed of coarse clastic detritus derived from erosion of the Limpopo Belt. Timing of the Limpopo orogeny, an event involving the collision of the Kaapvaal and Zimbabwe cratons, has long been a contentious issue. The results of point counting, major and trace element geochemistry, and $\mathrm{U}-\mathrm{Pb}$ detrital zircon geochronology indicate that the Waterberg sedimentary formations in the study area were primarily sourced by siliceous (rifted margin) sedimentary and minor mafic volcanic rocks of the Archean Beit Bridge Complex, Limpopo Central Zone.

The volumetrically predominant beige/brown sandstones in the four studied formations are quartzrich with average QFR ratios of 80:7:13 (Blouberg), 70:19:11 (Setlaole), 88:5:7 (Makgabeng), and 89:3:8 (Mogalakwena). Chert and arenite account for $>90 \%$ of lithic fragments in all formations, with minor siliceous gneiss fragments. Although all formations are silica enriched, the Makgabeng dune samples produce extremely high $\mathrm{SiO}_{2}$ abundances (92-99 wt\%), which are attributed to the presence of silica cement and quartz within rock fragments. Geochemically, the stratigraphically highest Mogalakwena Formation is unique with elevated Ti and $\mathrm{Zr}$ values, and intra-formational differences in REE patterns; the latter feature is consistent with a mixed provenance. Volumetrically minor green and purple sandstones in the Waterberg formations contain the greatest $\mathrm{Cr}, \mathrm{Ni}, \mathrm{Ti}$, and $\mathrm{V}$ abundances, which supports localized derivation from a mafic or ultramafic source. Chemical index of alteration (CIA) values range from 57 to 89 , which could indicate significant chemical weathering of the source rocks, but a plot of $\mathrm{Th} / \mathrm{Sc}$ versus $\mathrm{Zr} / \mathrm{Sc}$ illustrates that the sandstones have undergone recycling, which was probably responsible for enrichments in $\mathrm{Al}_{2} \mathrm{O}_{3}$ relative to $\mathrm{Na}_{2} \mathrm{O}_{3}, \mathrm{CaO}$ and $\mathrm{K}_{2} \mathrm{O}$. Combinations of well rounded and subangular quartz grains support a recycled origin. Detrital zircons in the lowermost Blouberg Formation produced a wide array of ages ranging from ca. 3379 to $2043 \mathrm{Ma}$. The youngest peak at $2046 \mathrm{Ma}$ is also the largest, and represents the maximum age of deposition for the formation. Additional peaks at $3281 \mathrm{Ma}, 3330 \mathrm{Ma}$, and $3379 \mathrm{Ma}$ are consistent with ages previously determined from the Beit Bridge Complex, whereas peaks at $2578 \mathrm{Ma}$ and $2649 \mathrm{Ma}$ coincide with ages determined from gneisses of the Limpopo Central Zone.

Derivation of detritus from the Beit Bridge Complex is directly indicated by sedimentary and siliceous gneiss fragments in the sandstones, subrounded quartz grains suggestive of relatively short transport distances, green and purple sandstone drapes derived from mafic volcanic units, and paleocurrent patterns consistent with south to southwest flow directions. Therefore the timing of deposition of the Blouberg Formation (2046 Ma) equates to the end stages of the Limpopo orogeny. This negates previous suggestions that the Limpopo orogeny occurred only during the Neoarchean.

\section{Introduction}

The Limpopo Belt is an orogen believed to have developed in response to collision between the Kaapvaal and Zimbabwe cratons

\footnotetext{
* Corresponding author.

E-mail address: pcorcor@uwo.ca (P.L. Corcoran).
}

(Fig. 1). Models for the evolution of the Limpopo Belt have focused on a Neoarchean (ca. 2.7 Ga) age for a single-stage collision (e.g.van Reenen et al., 1992; Roering et al., 1992; Rollinson, 1993; McCourt and Armstrong, 1998), whereas Paleoproterozoic (2.04-1.97 Ga) ages have also been determined throughout the central parts of the belt and along associated shear zones (e.g. Kamber et al., 1995; Holzer et al., 1998; Schaller et al., 1999). More complex models (e.g. Barton et al., 2006) envisage the Limpopo Belt to have been 


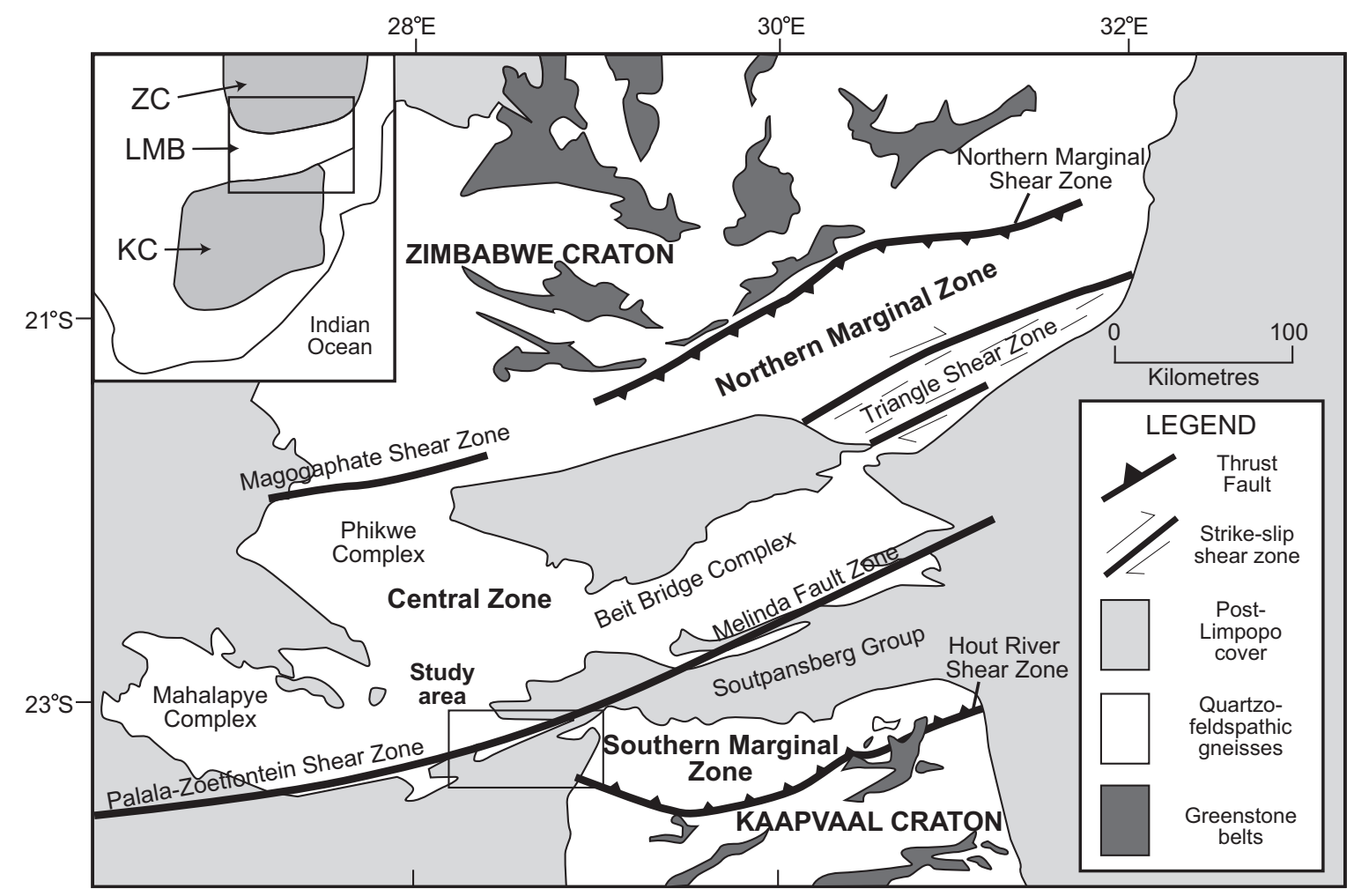

Fig. 1. Simplified geological map showing features of the Limpopo Belt in relation to the study area. KC, Kaapvaal Craton; LMB, Limpopo Mobile Belt; ZC, Zimbabwe Craton. Modified from Kröner et al. (1999), Roering et al. (1992), and Barton et al. (2006).

active throughout an extended period of time (ca. $2.7-2.04 \mathrm{Ga}$ ) with many separate orogenic events, which could explain the different P-T-t paths extrapolated from various areas. Bumby et al. (2004) interpreted the long history of post-Limpopo sedimentation and the development of numerous unconformities within these strata, to favor a Neoarchean age for the high-grade metamorphism in the southern parts of the Limpopo Belt. This would have allowed ca. 600 million years for the exhumation of high-grade Limpopo rocks prior to the nonconformable deposition of the lowermost Waterberg unit, the Blouberg Formation. The authors considered Paleoproterozoic ages in the central and southern part of the Limpopo Belt to reflect metamorphism during localized reactivation. This is in contrast to the recent publication by Kramers and Mouri (2011) who, based on a geochronological review, suggest the occurrence of two distinct tectono-metamorphic events during the late Archean and Paleoproterozoic. In addition, Barton et al. (2006) envisage the Palaeoproterozoic event as the last stage in juxtaposition of the Zimbabwe and Kaapvaal cratons along the Palala-Zoetfontein Shear Zone (PZSZ).

The study area contains four formations of the Waterberg Group that are separated by unconformities (Figs. 2 and 3). The durations of missing time represented by these hiatuses are unknown, although based on structural interpretations, Bumby et al. (2001a) suggested that the strata were deposited during two distinct phases, represented by the (1) Blouberg Formation, and (2) Makgabeng and Mogalakwena formations. The Setlaole Formation, which underlies the Makgabeng strata, may be correlative with the Blouberg Formation, but poor outcrop exposure of the Setlaole deposits has made stratigraphic characterization challenging. Fluvial paleocurrent patterns determined from the Setlaole, Makgabeng and Mogalakwena formations indicate flow to the south-southwest, which suggests a similar northern source terrane for the upper Waterberg strata (Bumby et al., 2001a). The basal Blouberg Formation displays a polymodal paleocurrent pattern, which is associated with its deposition in a pull-apart basin along the Melinda Fault zone, a reactivation structure of the PZSZ. Dorland et al. (2006) determined U-Pb zircon dates of $2054 \pm 4 \mathrm{Ma}$ and $2051 \pm 8 \mathrm{Ma}$ from lavas near the base of the Waterberg Group south of the study area (Lower Swaershoek and Rust de Winter Formations). Hanson et al. (2004) obtained U-Pb dates of ca. $1.92-1.87 \mathrm{Ga}$ for baddeleyite in dolerite dykes that cut the Mogalakwena Formation, suggesting that the lower and medial strata of the Waterberg Group were deposited prior to $1.9 \mathrm{Ga}$. Such an early onset of deposition seems unlikely in the most northerly part of the basin, where ductile deformation along the PZSZ seems to have continued until $1.97 \mathrm{Ga}$ (Schaller et al., 1999). However, it is also possible that the syn-tectonic Blouberg strata preserved along the PZSZ (and unconformably overlain by the $>1.9 \mathrm{Ga}$ Mogalakwena Formation) represent deposition during, or immediately after the final stages of Limpopo accretion at $2.04 \mathrm{Ga}$.

One of the major objectives of this paper is to present new petrographic and geochemical data that when combined with previous facies analyses and paleocurrent determinations, indicate that the Blouberg Formation was deposited during the Limpopo orogenic event. Establishing that deposition of the Waterberg strata was synchronous with uplift and erosion caused during collision of the Kaapvaal and Zimbabwe cratons is a significant step toward determining the timing of the Limpopo orogeny. Our second major objective is to use $\mathrm{U}-\mathrm{Pb}$ detrital zircon and monazite ages from the Blouberg Formation in order to constrain the age of termination of the Limpopo event.

\section{General geology}

The Waterberg Group of southern Africa is a clastic sedimentary succession preserved across the northern part of the Kaapvaal Craton, and is generally thought to have been deposited during the late Palaeoproterozoic. The strata that characterize the northern-most 


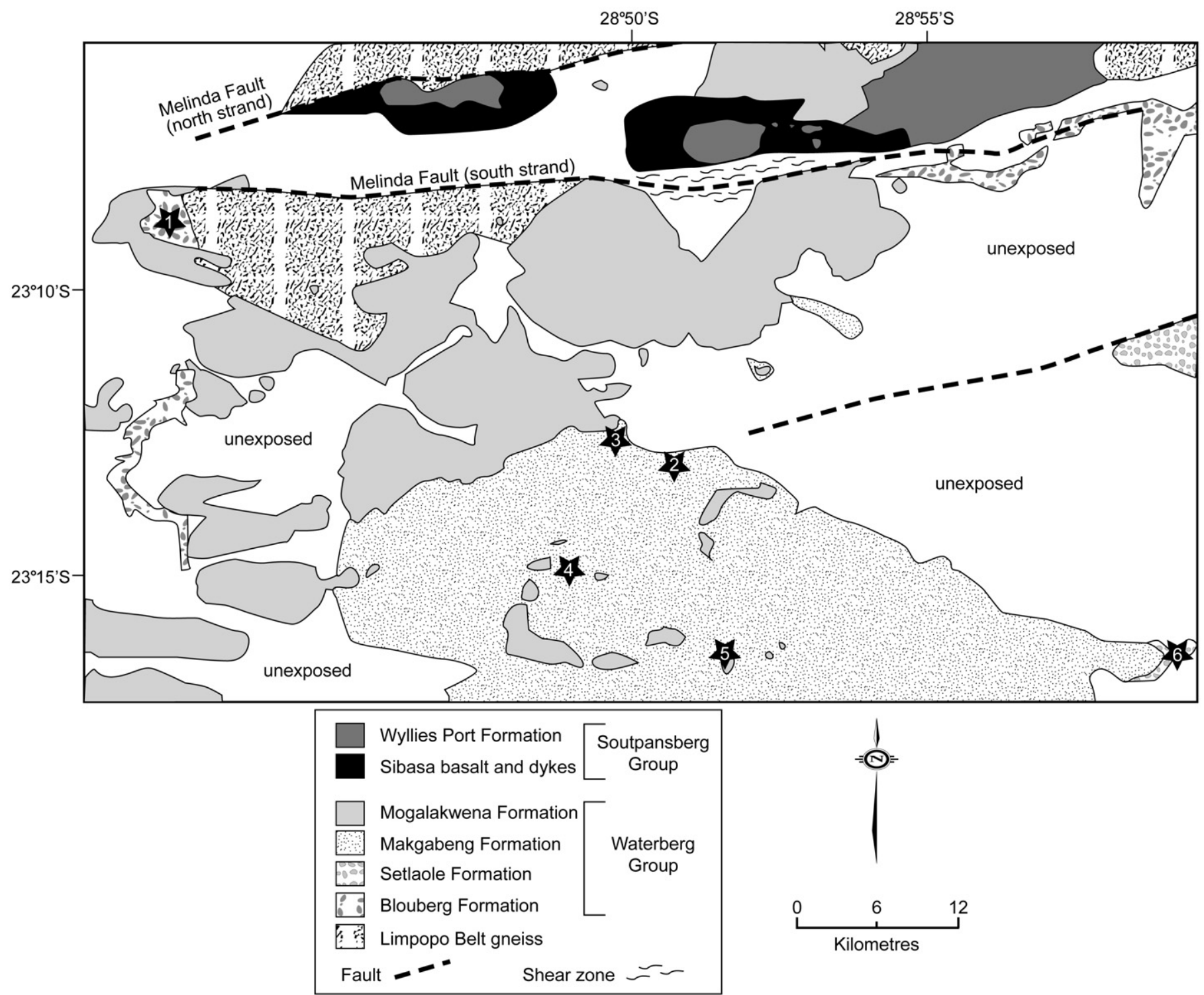

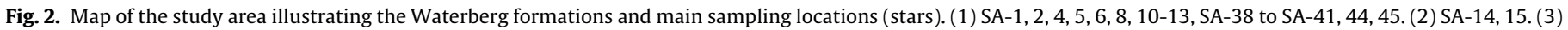
SA-16. (4) SA-17, 18. (5) SA-19-29. (6) SA-30 to SA-35, 37.

Modified from Eriksson et al. (2006).

part of the Waterberg basin unconformably overlie high-grade rocks of the Limpopo Belt. There remains little consensus regarding the style of deformation in the Limpopo Belt, although it has been considered at least partly analogous to a Himalayan- (e.g. Treloar et al., 1992) transpressional- (e.g. Holzer et al., 1998) or Turkic-type (Barton et al., 2006) orogeny. The Limpopo Belt is characterized by a number of shear zone-bound terranes, which lie between the cratons (Fig. 1). The Southern Marginal and Northern Marginal zones (SMZ and NMZ) are on the edges of the Kaapvaal and Zimbabwe cratons respectively, and are interpreted as rocks of the neighboring craton, but at a much higher grade, that were thrust onto their host craton during orogenic events. Between the SMZ and NMZ are a number of other terranes, such as the Beit Bridge, Phikwe and Mahalapye Complexes, which together have become termed the Central Zone (CZ; Fig. 1; Barton et al., 2006). There is some consensus that the SMZ, which largely forms the basement to the Waterberg Group, was thrust southwards along the Hout River Shear Zone during a Neoarchean event (e.g. Barton et al., 2006). The Palala-Zoetfontein Shear Zone (PZSZ; Fig. 1) marks the boundary between the SMZ (northernmost Kaapvaal Craton) and the CZ, and underlies the present study area. Barton et al. (2006) and Schaller et al. (1999) proposed that the final juxtaposition of the Zimbabwe Craton (together with the previously assembled NMZ and CZ terranes) with the northern edge of the SMZ took place along the PZSZ during the ca. 2.04 event. Schaller et al. (1999) suggested that ductile dextral strike-slip, post-orogenic shearing along the PZSZ continued between ca. 2.0 and $1.9 \mathrm{Ga}$, and this movement may account for the development of some of the sedimentary formations described below. In a similar vein Bumby et al. (2001a) suggested that strike-slip and southwards-vergent tectonics along the Melinda Fault Zone (a brittle reactivation of the PZSZ) at ca. $2.0 \mathrm{Ga}$ were responsible for the development of the Waterberg basins along the northern edge of the Kaapvaal Craton.

The Waterberg strata that are preserved along the Melinda Fault Zone suggest at least two phases of basin development. The first phase of basin development is associated with deposition of the Blouberg Formation (Fig. 4a), which is only preserved in localized areas, directly along the trace of the Melinda Fault Zone. The Blouberg strata are locally up to $1400 \mathrm{~m}$ thick, despite their limited areal extent, and contain an upward-coarsening 
A

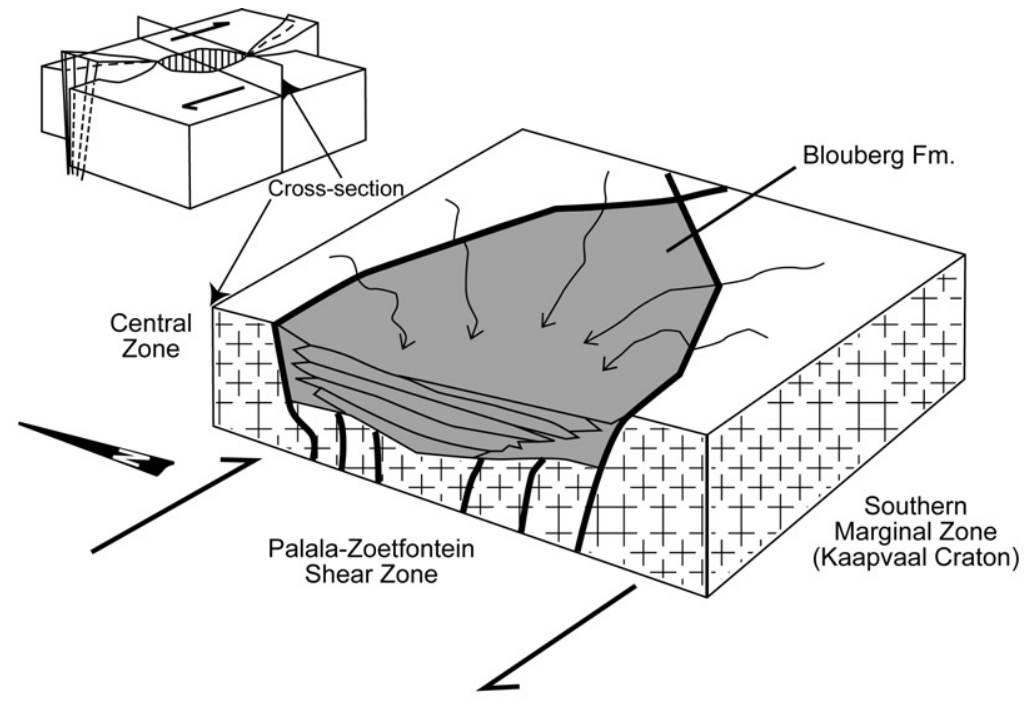

B
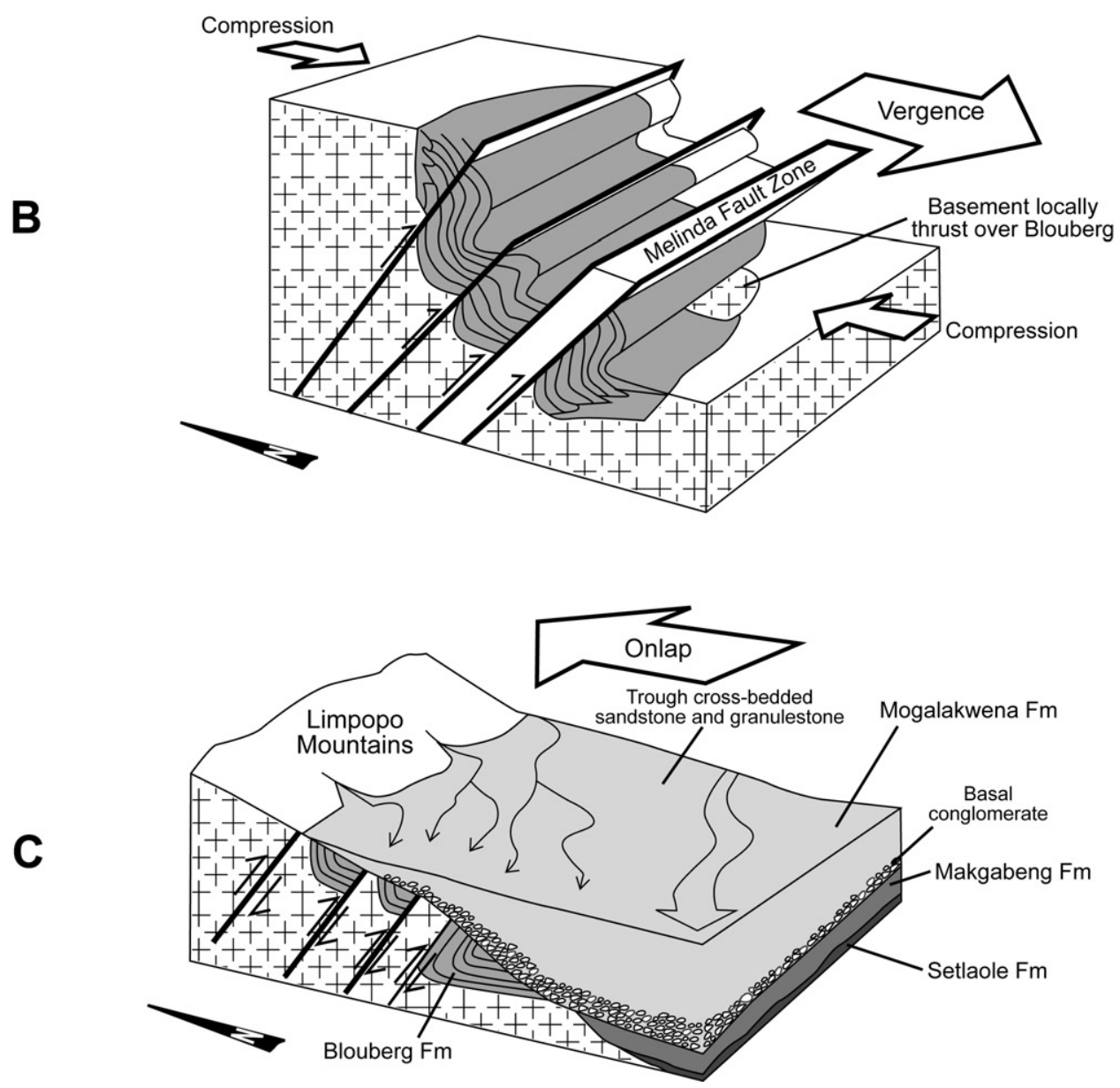

Fig. 3. Schematic block diagrams illustrating the development of the northern part of the Waterberg basin. Modified from Bumby et al. (2001a).

succession of trough cross-bedded granular sandstones, and an upper sedimentary breccia containing angular boulders of foliated feldspathic gneiss. Bumby et al. (2001a) interpreted these strata as a syntectonic succession that was deposited in rapidly subsiding pull-apart basin that developed as a result of strike-slip movement along the Melinda Fault. The radial, generally west-directed patterns of paleocurrents recorded in the Blouberg Formation support such a tectonic setting. Although the Blouberg Formation has been affected by very low-grade metamorphism, it is nevertheless strongly deformed. Bedding planes dip sub-vertically, or are overturned and dip northwards. Folded Blouberg strata have an E-W trending fold axis, and are locally affected by southward-vergent thrusts (Fig. 4b).

The second phase of basin development at the northern edge of the Waterberg basin is associated with deposition of the Setlaole, Makgabeng and Mogalakwena formations. The lowermost Setlaole 

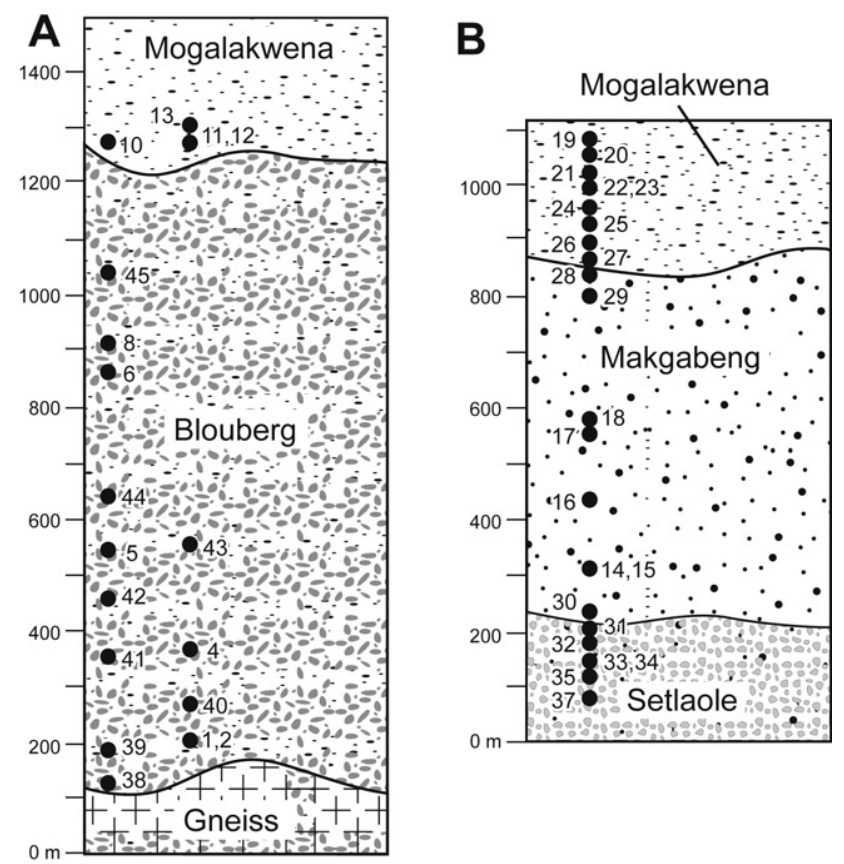

Fig. 4. Schematic stratigraphic sections of the Waterberg formations in the study area. (A) Blouberg unconformably overlies gneissic basement and is unconformably overlain by the Mogalakwena Formation in the northwest part of the study area (see Fig. 2). (B) Blouberg is absent in the southeast part of the study area where the Mogalakwena strata is underlain unconformably by the Makgabeng Formation.

Formation is only locally exposed, but it may correlate with the Blouberg Formation, as both strata seem to have been deposited nonconformably on gneiss of the SMZ. However the Setlaole Formation is not affected by any of the deformation typical of the Blouberg Formation, and thus may be younger. The extensive outcrops of the generally aeolian Makgabeng Formation appear to thin toward the north, and are nowhere developed close to the Blouberg Formation. Bumby et al. (2001a) proposed that Makgabeng strata onlapped northward over Limpopo mountains that had been created during southward-vergent tectonics that deformed the Blouberg strata (Fig. 4c). Although the Makgabeng Formation is generally composed of aeolian foresets, localized fluvial facies indicate southward-flowing palaeocurrent directions, similarly implying uplifted areas in the north. The Mogalakwena Formation is composed of granular sandstone, interbedded siltstone and quartz-conglomerate sheets that were deposited disconformably on the Makgabeng Formation. Toward the north, where the Makgabeng Formation does not crop out, the Mogalakwena Formation was deposited directly on steeply-dipping Blouberg strata, and a sharp angular unconformity is preserved (Fig. 4c). The Mogalakwena Formation thins northward across the width of the PZSZ, which suggests that the northward onlapping relationship across the craton edge was preserved throughout at least medial Waterberg times. Palaeocurrent directions recorded in the Mogalakwena Formation are unimodal toward the SW (Fig. 4c).

Additional sedimentary deposits in the area are those of the younger Soutpansberg Group, where basalt of the Sibasa Formation and quartzite of the Wyllie's Poort Formation overlie the Mogalakwena Formation on a slight angular unconformity (Bumby et al., 2001b; Fig. 2). These Soutpansberg strata are similarly preserved only along and parallel to the northern edge of the Kaapvaal Craton, approximately along the trace of the PZSZ, and have been interpreted to have been deposited in a post-Waterberg half-graben developed along the cratonic margin (Bumby et al., 2002).

\section{Waterberg Paleoenvironments}

Detailed descriptions and interpretations of the lithofacies composing the Blouberg, Setlaole, Makgabeng and Mogalakwena formations are provided in Bumby (2001) and Bumby et al. (2001a). This section briefly reviews the major sedimentary structures and bedforms characterizing each unit, and the interpretations of depositional processes and environments.

The Blouberg Formation unconformably overlies gneissic basement, and is unconformably overlain by the Mogalakwena Formation (Fig. 3). Blouberg Formation sandstones are very coarse grained to granular, and on the weathered surface are beige and purple in color, with thin, green siltstone drapes developed locally on foresets and between bedforms. The lower, sandstonedominated portion of the Blouberg Formation mainly contains medium- to large-scale sets of trough and planar cross-beds, and local granule- to pebble-filled channel forms (Fig. 5a). The trough cross-bedded sandstone developed as sinuous crested dunes on longitudinal bars, whereas the planar cross-beds are considered to have formed as linguoid bars (Miall, 1978) or bar-top sands (Best and Bridge, 1992). The generally west-flowing paleocurrent directions determined from cross-bed measurements, combined with a predominance of bedload material over suspended detritus support a low-sinuosity braided sheetflood system (Miall, 1992). The upper portion of the Blouberg Formation is composed of crudely to well stratified, matrix- to clast-supported conglomerate with subangular to rounded clasts (Fig. 5b). Planar and trough cross-bedded sandstone interbeds are in places well developed. Matrixsupported units are interpreted as debris flow deposits (Mack and Rasmussen, 1984), whereas clast-supported conglomerates represent longitudinal gravel bars in a stream-dominated alluvial fan (Collinson, 1996) or proximal braided stream setting. Interstratified trough cross-bedded and planar sandstone beds represent in-channel dunes and bar top sands, respectively (Eriksson, 1978). The abrupt transition from sandstone- to conglomerate-dominated strata is considered a response to tectonic activity in the source area. Eriksson et al. (2006) determined, based on paleohydraulic calculations, a general increase in stream discharge, drainage area, and length toward the center of the preserved Blouberg basin, and combined with the preservation of the Blouberg Formation along the PZSZ, points toward deposition in a pull-apart basin.

The relatively poorly exposed Setlaole Formation is overlain by the Makgabeng Formation, and mainly contains trough crossbedded and planar bedded sandstone (Figs. 4 and 5c). The former structure is consistent with in-channel migration of sinuouscrested dunes (Mueller et al., 1994), whereas planar beds represent bar-top sands (Eriksson, 1978). A relatively unimodal southerly palaeocurrent pattern supports a fluvial interpretation (Bumby et al., 2001a). The lack of mudstone in both the Setlaole and Blouberg formations points toward a braided fluvial environment, which is consistent with the absence of land plants during the Precambrian (Long, 2011).

The Makgabeng Formation overlies the Setlaole Formation and is unconformably overlain by the Mogalakwena Formation (Figs. 3 and 5d). It is considered to represent mainly aeolian sedimentation based on inverse-grading of sand grains in laminations (c.f. Hunter, 1977, 1981; Kocurek and Dott, 1981), ripple indices indicating wind transport (Bumby, 2001), and planar cross-bedded strata with steep angles of inclination (Fig. 5e) consistent with sinuous-crested or barchanoid sand dunes (c.f. McKee, 1979). The well-exposed formation is composed of five lithofacies, which include: (1) large-scale trough and planar cross-bedded sandstone, (2) horizontally bedded and rippled mudstone and sandstone, (3) rippled and cross-bedded sandstone, (4) massive sandstone, and (5) pebbly sandstone (Bumby, 2001). Of these, the strongest evidence for arid conditions appears in the horizontally bedded and 

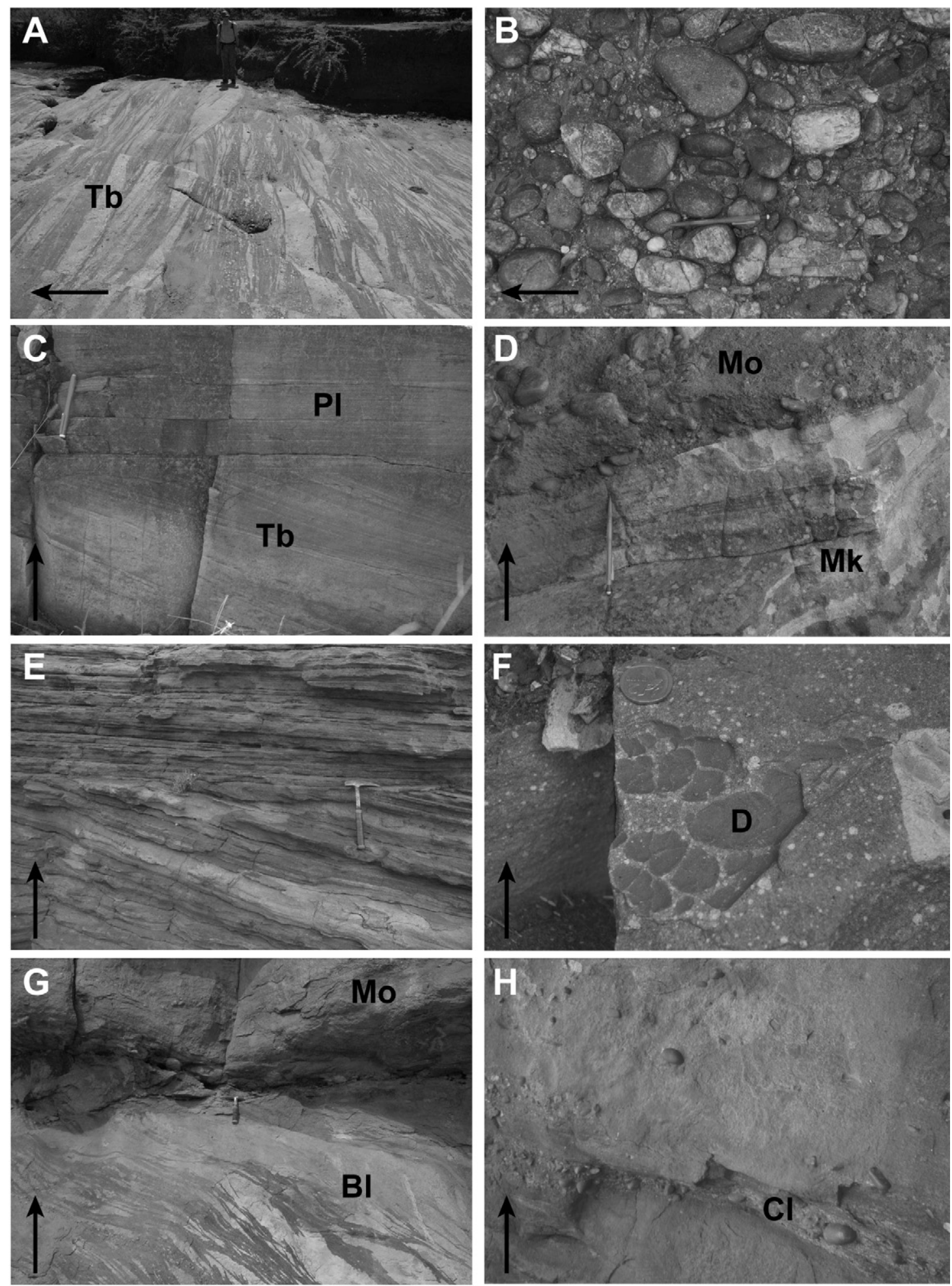

Fig. 5. Characteristics of the Waterberg formations. Younging directions are indicated by large arrows. Scales include pencil $(14 \mathrm{~cm})$, person $(180 \mathrm{~cm})$, hammer, $(50 \mathrm{~cm})$ and coin $(2.5 \mathrm{~cm})$. (A) Large-scale trough crossbeds (Tb) in the Blouberg Formation. (B) Clast-supported conglomerate in the Blouberg Formation. Note the rounded to well rounded cobbles, which are composed of gneiss, quartz arenite and sandstone. (C) Trough crossbeds (Tb) and planar beds (Pl) in the Setlaole Formation. (D) Disconformity between the Makgabeng (Mk) and Mogalakwena (Mo) formations. (E) Planar cross-bedded sandstone of the Makgabeng Formation. (F) Desiccation cracks in the interdune sandstone of the Makgabeng Formation. (G) Angular unconformity between the Blouberg (Bl) and Mogalakwena (Mo) formations. (H) Conglomerate lens in sandstone of a fining-upward cycle in the Mogalakwena Formation.

rippled mudstone and sandstone lithofacies. Heavy precipitation is inferred to have formed the lower-most massive, stratified, and current-rippled sandstone, whereas overlying wind-rippled sandstone, desiccation cracks, evaporite casts and roll-up structures represent drying up of muds (Fig. 5f) (Eriksson et al., 2000). This lithofacies is interpreted as interdune deposits in a playa lake setting, based on its association with underlying horizontally inclined dune foresets (Bumby, 2001; Simpson et al., 2004). 
Additional evidence of periodic arid conditions is provided in the lenticular and channelized, massive sandstone lithofacies. Sedimentary structures include dewatering and dessication features on bed surfaces, and soft-sediment deformation of steeply dipping aeolian foresets. These structures, combined with onlap of the massive beds onto dune foresets, are consistent with deposition of water-saturated sand that slumped down the lee faces of sand dunes (Simpson et al., 2004). Slope failure was probably caused by periodic torrential rainfall (e.g. Loope et al., 1999). The massive sandstone lithofacies becomes more predominant toward the top of the Makgabeng stratigraphy, which points toward increasingly wetter conditions over time.

The Mogalakwena Formation overlies the Blouberg and Makgabeng formations unconformably (Figs. 4 and $5 \mathrm{~g}$ ), and in its lower part, is primarily composed of conglomerate and interbedded trough cross-bedded sandstone. The lower deposits represent coarse-grained sandstone sheets and local conglomerate-filled channels, indicating migration of braided fluvial channels (Miall, 1992). The upper part of the Mogalakwena Formation, which is well preserved in the northern part of the basin, is composed of distinct, $1.5-4 \mathrm{~m}$ thick fining-upward cycles of conglomerate, granular to pebbly sandstone, and siltstone. Within each cycle, the predominantly matrix-supported conglomerate varies from massive to planar and trough cross-bedded. The overlying granular to pebbly sandstone is trough cross-bedded and contains local conglomerate lenses (Fig. 5h). Up-section, the sandstone becomes finer and is mainly low-angle laminated. Most cycles contain an upper parallel laminated siltstone. The fining-upward cycles are similar to those described by Cant and Walker (1976), albeit much coarser grained. The deposits are considered to have formed in a braided stream environment in which conglomerate and lower sandstone are considered in-channel deposits, and the upper sandstone and siltstone represent bar-top deposits. Unimodal palaeocurrent directions recorded from the Mogalakwena Formation suggest that river channels were flowing from the NE and ENE. This paleocurrent direction is displayed by a facies change toward the SW where thick, clast-supported conglomerate near the southern strand of the Melinda Fault becomes subordinate toward the SW. Therefore, the conglomeratedominated deposits in the east are considered proximal, and trough cross-bedded sandstone in the west is the distal facies equivalent.
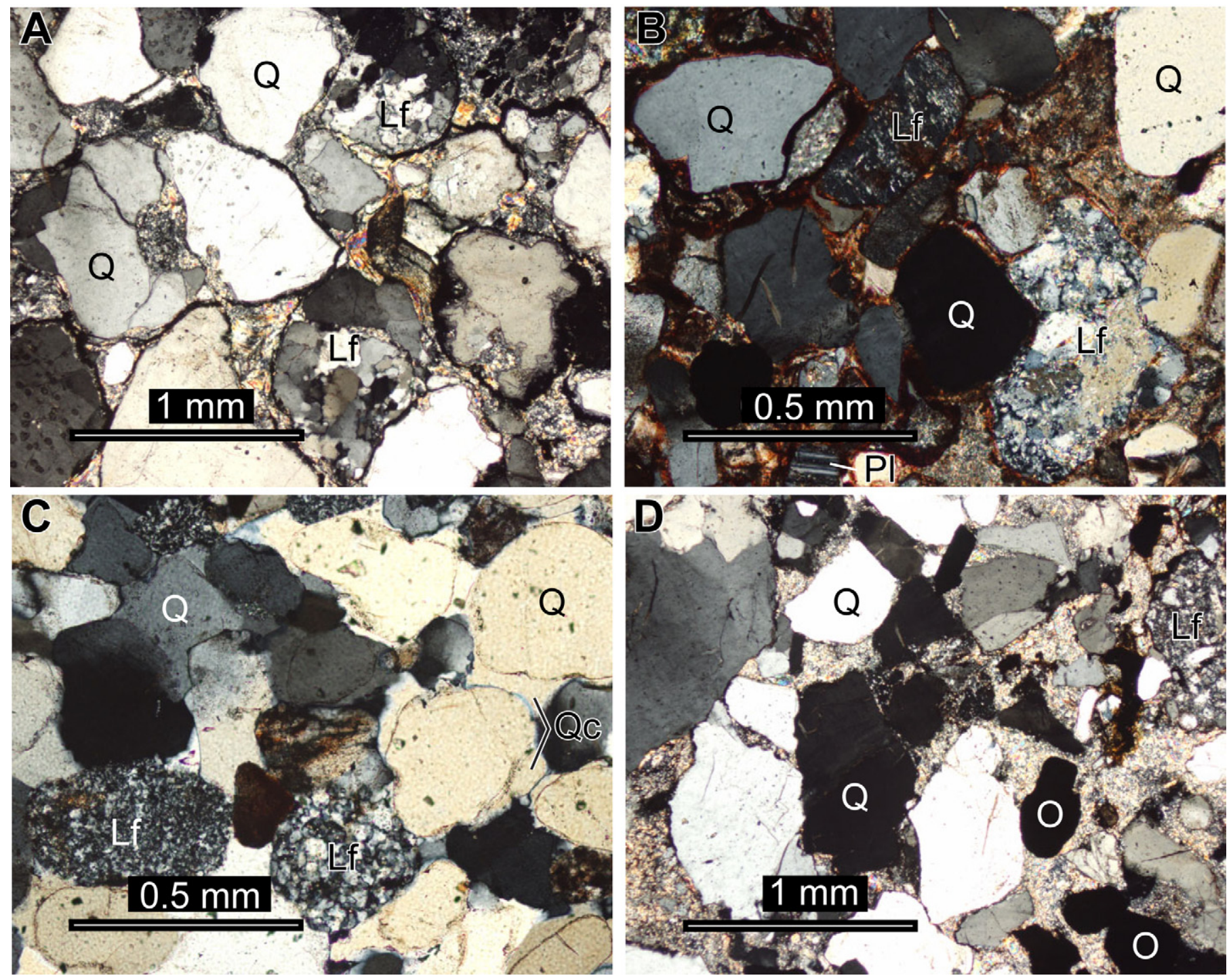

Fig. 6. Petrographic characteristics of the Waterberg formations in the study area. (A) Blouberg sample SA-11-38 containing subrounded quartz (Q) and lithic fragments (Lf). (B) Setlaole sample SA-11-31 displaying subrounded quartz (Q), plagioclase (PI), and gneissic and sedimentary lithic fragments (Lf). (C) Makgabeng sample SA-11-16 containing rounded quartz $(\mathrm{Q})$ and sedimentary lithic fragments (Lf). Note the silica cement (Qc) between grains. (D) Mogalakwena sample SA-11-23 displaying subangular to subrounded quartz $(\mathrm{Q})$, lithic fragments $(\mathrm{Lf})$, and opaque minerals $(\mathrm{O})$. 
Table 1

Recalculated point counting results from sandstones, siltstones, and sandstone interbeds of the Blouberg, Setlaole, Makgabeng, and Mogalakwena formations. Grain parameters include: $\mathrm{Q}=\mathrm{Qm}+\mathrm{Qp}$ where $\mathrm{Qm}$ is monocrystalline quartz and $\mathrm{Qp}$ is polycrystalline quartz; $\mathrm{F}=\mathrm{P}+\mathrm{K}$ where $\mathrm{P}$ is plagioclase feldspar and $\mathrm{K}$ is potassium feldspar; $\mathrm{R}=$ rock (lithic) fragments.

\begin{tabular}{|c|c|c|c|c|c|c|c|c|c|c|c|c|c|}
\hline Sample & Formation & $\mathrm{Qm}$ & Qp & Q & $\mathrm{Qp} / \mathrm{Q}$ & $\mathrm{P}$ & $\mathrm{K}$ & $\mathrm{F}$ & $\mathrm{P} / \mathrm{F}$ & Lt & $\mathrm{Ma} \%$ & Total & QFR/QFL \\
\hline SA-11-1 & Blouberg & 170 & 17 & 187 & .09 & 8 & 17 & 25 & .32 & 8 & 15 & 304 & $81: 11: 8$ \\
\hline SA-11-6 & Blouberg interbed & 121 & 4 & 125 & .03 & 9 & 5 & 14 & .64 & 83 & 15 & 300 & $56: 6: 38$ \\
\hline SA-11-38 & Blouberg & 202 & 9 & 211 & .04 & 1 & 7 & 8 & .13 & 47 & 14 & 309 & 79.5:3.5:17 \\
\hline SA-11-39 & Blouberg & 178 & 32 & 210 & .15 & 10 & 5 & 15 & .67 & 44 & 12 & 305 & $78: 6: 16$ \\
\hline SA-11-43 & Blouberg & 185 & 23 & 208 & .11 & 7 & 13 & 20 & .35 & 25 & 3 & 304 & $82: 8: 10$ \\
\hline SA-11-10 & Mogalakwena & 183 & 14 & 197 & .07 & 7 & 7 & 14 & .5 & 13 & 18 & 306 & $88: 6: 6$ \\
\hline SA-11-12 & Mogalakwena & 98 & 47 & 145 & .32 & 9 & 5 & 14 & .64 & 74 & 19 & 300 & $62: 6: 32$ \\
\hline SA-11-19 & Mogalakwena & 185 & 43 & 228 & .19 & 0 & 7 & 7 & 0 & 29 & 13 & 303 & $86: 3: 11$ \\
\hline SA-11-20 & Mogalakwena & 171 & 49 & 220 & .22 & 1 & 1 & 2 & .5 & 16 & 20 & 300 & $93: 1: 6$ \\
\hline SA-11-23 & Mogalakwena & 204 & 37 & 241 & .15 & 0 & 5 & 5 & 0 & 21 & 12 & 304 & $90: 2: 8$ \\
\hline SA-11-24 & Mogalakwena & 179 & 45 & 224 & .20 & 2 & 6 & 8 & .25 & 18 & 19 & 305 & $90: 3: 7$ \\
\hline SA-11-25 & Mogalakwena & 239 & 45 & 284 & .16 & 7 & 5 & 12 & .58 & 27 & 18 & 380 & $86: 6.5: 8.5$ \\
\hline SA-11-27 & Mogalakwena & 237 & 38 & 275 & .14 & 1 & 3 & 4 & .25 & 25 & 14 & 355 & $90.5: 1.5: 8$ \\
\hline SA-11-28 & Mogalakwena & 250 & 6 & 256 & .02 & 2 & 4 & 6 & .33 & 31 & 6 & 312 & $87: 2: 11$ \\
\hline SA-11-14 & Makgabeng interdune & 213 & 9 & 222 & .40 & 9 & 21 & 30 & .30 & 40 & 7 & 313 & $76: 10: 14$ \\
\hline SA-11-15 & Makgabeng & 211 & 14 & 225 & .06 & 0 & 18 & 18 & 0 & 28 & 10 & 304 & $83: 7: 10$ \\
\hline SA-11-16 & Makgabeng & 235 & 1 & 236 & 0 & 0 & 23 & 23 & 0 & 30 & 5 & 303 & $81.5: 8: 10.5$ \\
\hline SA-11-17 & Makgabeng & 241 & 8 & 249 & .03 & 0 & 15 & 15 & 0 & 17 & 12 & 318 & $89: 5: 6$ \\
\hline SA-11-18 & Makgabeng & 248 & 13 & 261 & .05 & 3 & 7 & 10 & .30 & 23 & 3 & 303 & $88: 4: 8$ \\
\hline SA-11-29 & Makgabeng & 295 & 13 & 308 & .04 & 0 & 1 & 1 & 0 & 17 & 0.5 & 328 & $94.5: 0.5: 0.5$ \\
\hline SA-11-30 & Makgabeng & 243 & 8 & 251 & .03 & 6 & 5 & 11 & .55 & 16 & 10 & 308 & $90: 4: 6$ \\
\hline SA-11-31 & Setlaole & 161 & 6 & 167 & .04 & 46 & 28 & 54 & .85 & 28 & 12 & 300 & $62: 27.5: 10.5$ \\
\hline SA-11-32 & Setlaole & 209 & 9 & 218 & .04 & 6 & 25 & 31 & .19 & 17 & 12 & 301 & $82.5: 11: 6.5$ \\
\hline SA-11-33 & Setlaole & 161 & 17 & 178 & .10 & 40 & 30 & 70 & .57 & 40 & 14 & 336 & $62: 24: 14$ \\
\hline SA-11-35 & Setlaole & 155 & 7 & 162 & .04 & 52 & 23 & 75 & .69 & 22 & 16 & 309 & $63: 29: 8$ \\
\hline SA-11-37 & Setlaole & 205 & 6 & 211 & .03 & 4 & 8 & 12 & .33 & 44 & 17 & 310 & $79: 5: 16$ \\
\hline
\end{tabular}

\section{Sandstone composition}

Twenty-six sandstone samples were point counted using the Indiana method, wherein rock fragments containing sand-size crystals were classified as individual rock fragments. A total of 300-380 grains were counted in order to evaluate mineralogy, sorting, grain size and roundness. Five Blouberg samples, 5 Setlaole samples, 7 Makgabeng samples, and 9 Mogalakwena samples were counted. Seven grain categories, including matrix (grains $<0.03 \mathrm{~mm}$ ) were chosen (Table 1 ). Certain grain parameters were calculated to determine overall composition, potential source rocks, and possible tectonic setting. These include combined monoand polycrystalline quartz $(\mathrm{Q})$, combined potassium and plagioclase feldspar $(\mathrm{F})$, the plagioclase to total feldspar ratio $(\mathrm{P} / \mathrm{F})$, the polycrystalline quartz/total quartz ratio $(\mathrm{Qp} / \mathrm{Q})$, and the relative percentages of quartz, feldspar and rock fragments (QFR/QFL). Sedimentary rock fragments are composed of arenite, arkose, and chert, whereas felsic volcanic and gneiss grains were also identified. Clasts in conglomerates of the Blouberg and Mogalakwena formations were identified as primarily gneiss, quartz arenite and chert.

Sandstones of the Blouberg Formation are very coarse-grained to granular, poorly to moderately sorted, and contain angular to subrounded grains (Fig. 6a). Monocrystalline quartz (Qm) is more common than polycrystalline quartz (Qp), with a $Q p / Q$ average of 0.09 , and the overall plagioclase (P) to total feldspar (F) ratio of 0.43 reflects a predominance of potassium feldspar. Lithic fragments (Lt) are mainly sedimentary, with very minor gneiss grains. With an average QFR ratio of 80:7:13, the sandstone samples plot mainly as sublitharenites (Fig. 7a), whereas the sandstone interbed sample plots as a litharenite with a ratio of 56:6:38. The matrix of sandstones and the sandstone interbed is dominated by white mica +quartz+-feldspar, and white mica+carbonate+quartz+feldspar, respectively.
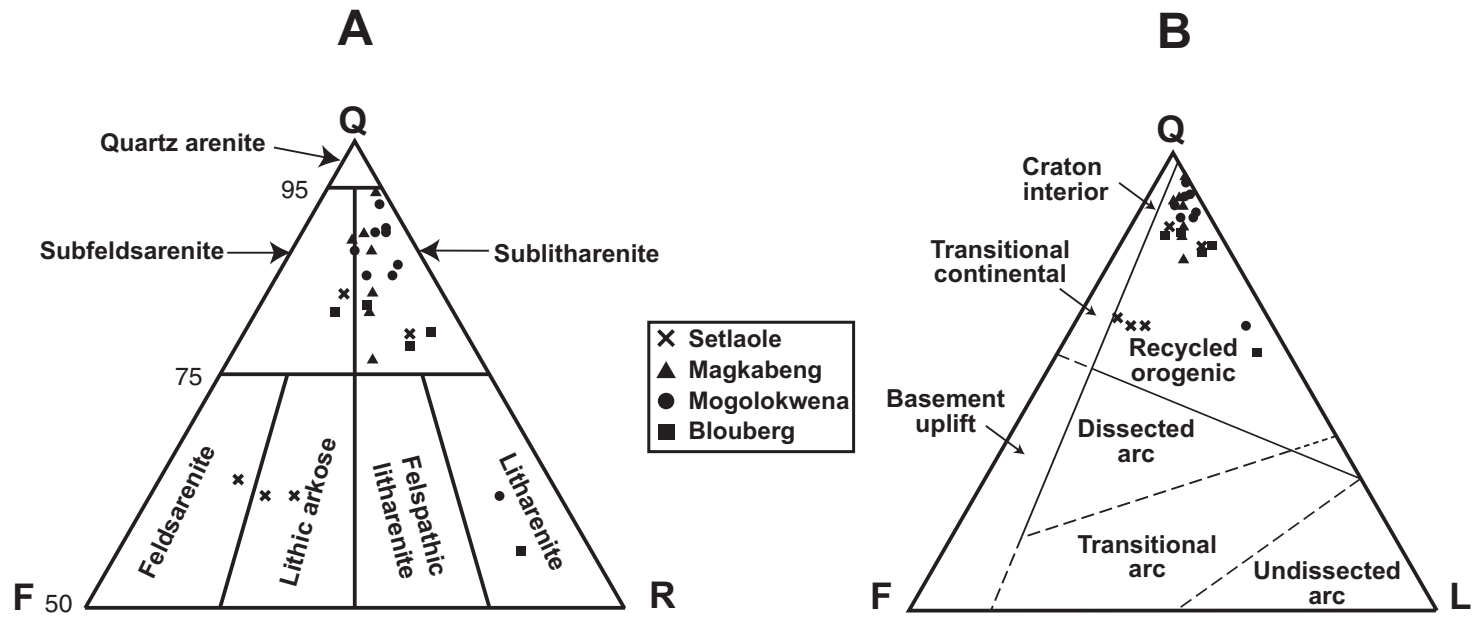

Fig. 7. Ternary diagrams illustrating the compositions of samples from the Blouberg, Setlaole, Makgabeng, and Mogalakwena formations. (A) QFR diagram of Folk et al. (1970), truncated at 50\% quartz. (B) QFL diagram of Dickinson et al. (1983) illustrates a recycled orogenic provenance for all the Waterberg samples. 
Setlaole sandstone samples are medium- to coarse-grained, poorly to moderately sorted, and contain subangular to subrounded grains (Fig. 6b). Monocrystalline quartz is much more common than polycrystalline varieties, as indicated by a $\mathrm{QP} / \mathrm{Q}$ ratio of 0.05 . A P/F ratio of 0.53 indicates that the Setlaole sandstones are the only formation containing more plagioclase than potassium feldspar (Table 1 ). Lithic fragments are mainly sedimentary, with very minor felsic volcanic and gneiss grains. Sandstones with $>75 \%$ quartz plot as sublitharenites and subfeldsarenites, whereas samples containing $<75 \%$ quartz fall into the lithic arkose and feldsarenite fields (Fig. 7a; average QFR ratio of 70:19:11). The matrix components include white mica + quartz +-feldspar, and silica and carbonate cement are common.

Samples from the Makgabeng Formation are medium- to coarsegrained, moderately to very well sorted, and contain subrounded to well rounded grains (Fig. 6c). One sample was collected from a unit identified by Eriksson et al. (2000) as an interdune deposit (SA-11-15), whereas all other samples were taken from dune facies. Qp/P and P/F ratio averages are 0.04 and 0.14 , respectively (Table 1). Lithic fragments are sedimentary. The sandstones all plot as sublitharenites with an average QFR ratio of 88:5:7 and 76:10:14 for the interdune sample (Fig. 7a). Matrix percentage in Makgabeng samples is much lower than in other formations, with an average of $7 \%$. The matrix of sandstones is dominated by white mica + quartz +-feldspar, and minor silica cement was identified.

Mogalakwena sandstone samples are coarse-grained to granular, poorly to moderately sorted, and contain subangular to rounded grains (Fig. 6d). The average $Q \mathrm{p} / \mathrm{Q}$ and $\mathrm{P} / \mathrm{F}$ ratios are 0.16 and 0.34 , respectively (Table 1 ). Lithic fragments are mainly sedimentary, with minor gneiss and felsic volcanic grains. With an average QFR ratio of 89:3:8, the samples plot as sublitharenites (Fig. 7a), except for a green sandstone (SA-11-12), which has a QFR ratio of 62:6:32, and contains abundant chlorite. Accessory minerals in the Mogalakwena samples include chlorite and muscovite, and opaque minerals. The matrix is composed of white mica + quartz + feldspar, and carbonate and silica cement are common in the sandstones of this formation.

In terms of basin and terrane analysis, samples from all formations plot in the recycled orogen provenance on the QFL diagram (Fig. 7b). This diagram reflects grain stability, which is a function of weathering and basin relief during erosion and transport (Dickinson and Suczek, 1979). Folded and faulted sedimentary rocks are generally considered the sources for sandstones plotting in this field of the ternary diagram (Dickinson and Suczek, 1979), although Corcoran et al. (1999) showed that gneissoplutonic sources could also produce deposits plotting as recycled orogenic.

\section{Geochemistry}

Twenty-seven sandstone samples, three sandstone interbed samples from conglomerate, and six siltstone samples were selected for geochemical analysis. The samples were analyzed at the Geoscience Laboratories of the Ontario Geological Survey. Major elements were determined using fused-disc X-ray fluorescence (XRF), and loss on ignition (LOI) values, as determined by gravimetric methods, range from 0.41 to 7.66 (Inline Supplementary Table S1). The rare earth elements (REE) and other trace elements were determined by Inductively Coupled Plasma-Mass Spectrometry (ICP-MS) (Inline Supplementary Table S2). The accuracy and precision of the methods are discussed in Longerich et al. (1990).

Inline Supplementary Tables S1 and S2 can be found online at http://dx.doi.org/10.1016/j.precamres.2012.12.009.

\subsection{Blouberg Formation}

Nine sandstone and three sandstone interbed samples from the Blouberg Formation were analyzed for major and trace elements (Inline Supplementary Tables S1 and S2). Brown to beige sandstones contain $80-87 \mathrm{wt} \% \mathrm{SiO}_{2}$ with $\mathrm{MgO}$ contents of 0.34-1.11 wt\%, whereas green sandstone drapes and horizons contain 68-74 wt\% $\mathrm{SiO}_{2}$ and 1.01-1.36 wt\% MgO. The green sandstone is also characterized by greater abundances of $\mathrm{Cr}, \mathrm{Ni}$, and $\mathrm{Ti}$, and a lower Th/Sc ratio (1.8) than in brown and beige sandstone (average $\mathrm{Th} / \mathrm{Sc}$ ratio of 2.6). Sandstone interbeds in conglomerate contain the least amounts of $\mathrm{SiO}_{2}$ with 65-66 wt\%, and the greatest abundances of $\mathrm{MgO}$ (1.9-2.37 wt\%) and $\mathrm{TiO}_{2}$ (0.28-0.43 wt\%) compared with all other Blouberg samples. As a whole, the Blouberg sandstones have an average Ti component of $1559 \mathrm{ppm}$, whereas the average $\mathrm{Zr}$ composition is $178 \mathrm{ppm}$ (Fig. 8a). The Chemical Index of Alteration (CIA; Nesbitt and Young, 1982) values, which determine climatic conditions at the time of source rock erosion and sediment deposition, range from 57 to 74 . Although the CIA values for some samples are high, these may reflect recycling and/or derivation from a quartz-rich sedimentary source that underwent a substantial amount of sorting prior to consolidation. When plotted on a Th/Sc versus Zr/Sc graph, all Waterberg samples display enrichments in $\mathrm{Th}$ and $\mathrm{Zr}$ relative to Sc (Fig. 8b). This supports enrichment in zircon, which typically occurs with enhanced sorting and multiple recycling episodes (McLennan et al., 1993). The Blouberg samples plot in the active continental margin (ACM) and passive continental margin (PM) fields on the $\mathrm{Sc}-\mathrm{Th}-\mathrm{Zr} / 10$ tectonic discrimination diagram (Fig. 9). Enrichments in Th and $\mathrm{Zr}$ supports derivation from a felsic-dominated source terrane.

Compared with chondrite (normalizing values from Haskin et al., 1968), four analyzed sandstones are light rare earth element (LREE) enriched with $\mathrm{La} / \mathrm{Yb}_{n}=13.44-25.55$ (Fig. 10), which correlates well with high Th values; both are consistent with derivation from a silicic source rock (Taylor and McLennan, 1985). The Sm/Yb ratios range from 2.88 to 4.93 , which may be consistent with enrichment in monazite, as this mineral forms a steep heavy REE pattern (McLennan et al., 1993). The presence of monazite in the sandstone samples supports derivation from a granitic source rock. The negative Eu anomalies produced by the Blouberg samples are the results of either low feldspar percentages in the sandstones and/or inheritance from igneous source rocks (McLennan and Taylor, 1991).

\subsection{Setlaole Formation}

Four sandstone and one siltstone sample from the Setlaole Formation were analyzed for major and trace elements (Inline Supplementary Tables S1 and S2). The sandstones contain $75-87 \mathrm{wt} \% \mathrm{SiO}_{2}$, with $\mathrm{MgO}$ wt\% contents of 0.06 to $1.08 \mathrm{wt} \%$, whereas the siltstone sample contains $73 \mathrm{wt} \% \mathrm{SiO}_{2}$ and $1.55 \mathrm{wt} \%$ MgO. The Setlaole samples on average are composed of $1334 \mathrm{ppm}$ Ti and $211 \mathrm{ppm} \mathrm{Zr} \mathrm{(Fig.} \mathrm{8a),} \mathrm{and} \mathrm{the} \mathrm{average} \mathrm{Th/Sc} \mathrm{ratio} \mathrm{is} \mathrm{1.7,}$ which is the lowest value of all Waterberg samples. Chemical index of alteration values could not be calculated for the Setlaole Formation because the abundance of carbonate cement in the samples has strongly increased the amount of $\mathrm{CaO}$ compared with other oxides used in the calculation. Enrichments in Th and $\mathrm{Zr}$ relative to $\mathrm{Sc}$, and a substantial increase in $\mathrm{Zr}$ compared with Th, supports recycling (Fig. 8b). Four of the five Setlaole samples plot in the continental volcanic arc (CVA) field on the tectonic discrimination diagram (Fig. 9) as a result of slightly higher Sc and lower Th values compared with samples from the other Waterberg formations. The results indicate that although the Blouberg and Setlaole formations have been considered possibly correlative, the source for the former deposits was not entirely the same as that for the latter. Chrondrite-normalized REE profiles for four Setlaole 

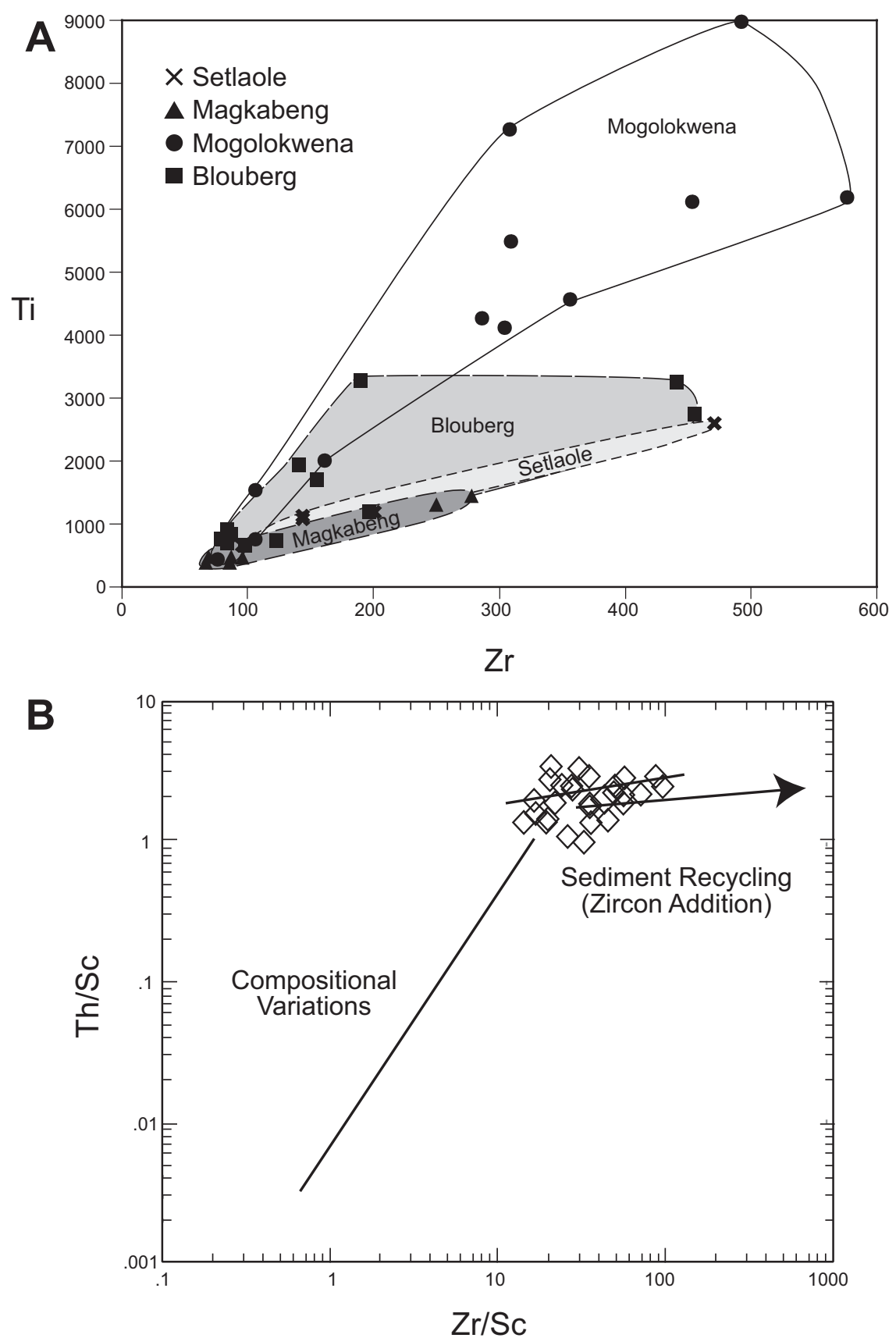

Fig. 8. Trace element discrimination diagrams for the Waterberg samples. (A) Plot of Ti/Zr illustrating a more mafic signature in the Mogalakwena Formation compared with the other three Waterberg formations. (B) Plot of $\mathrm{Th} / \mathrm{Sc}$ versus $\mathrm{Zr} / \mathrm{Sc}$ illustrating a sediment recycling trend formed by the Waterberg samples.

Plot from McLennan et al. (1993).

sandstone samples show HREE depletion with $\mathrm{La} / \mathrm{Yb}_{n}=7.29-13.65$ (Fig. 10). The enrichment in LREE in addition to a $\mathrm{Sm} / \mathrm{Yb}_{n}$ ratio of 2.44-3.27 supports a felsic-dominated source terrane. The sandstones show little to know negative Eu anomalies,which reflects the abundance of plagioclase ( $\mathrm{QFR}$ ratio of $70: 19: 11 ; \mathrm{P} / \mathrm{F}=0.53$ ) in the samples compared with the other Waterberg formations.

\subsection{Makgabeng Formation}

Six sandstone samples from the Makgabeng Formation were analyzed for major and trace elements (Inline Supplementary Tables $\mathrm{S} 1$ and S2). The dune facies samples contain $92-99 \mathrm{wt} \% \mathrm{SiO}_{2}$, with $\mathrm{MgO}$ contents of $<0.01-0.84 \mathrm{wt} \%$. The high $\mathrm{SiO}_{2}$ percentages can be attributed to abundant quartz grains, quartz within sedimentary rock fragments, and silica cement that characterizes this formation. In contrast, the interdune sample contains $83 \mathrm{wt} \% \mathrm{SiO}_{2}$ and $0.52 \mathrm{wt} \% \mathrm{MgO}$. The Makgabeng sandstones contain the lowest amounts of $\mathrm{Ti}$ and $\mathrm{Zr}$ of all the Waterberg samples, with averages of $587 \mathrm{ppm}$ and $109 \mathrm{ppm}$, respectively (Fig. 8a). The average Th/Sc ratio is 2.4 , which is the same as the average ratio calculated for the Mogalakwena Formation. The CIA values for the Makgabeng dune facies samples range from 67 to 83 , which is slightly higher than the Blouberg samples, and suggests either a chemically weathered source or substantial recycling. The samples fall along the sediment recycling trend on the $\mathrm{Th} / \mathrm{Sc}$ versus $\mathrm{Zr} / \mathrm{Sc}$ plot (Fig. $8 \mathrm{~b}$ ). All Makgabeng sanstones plot within the passive margin (PM) field 


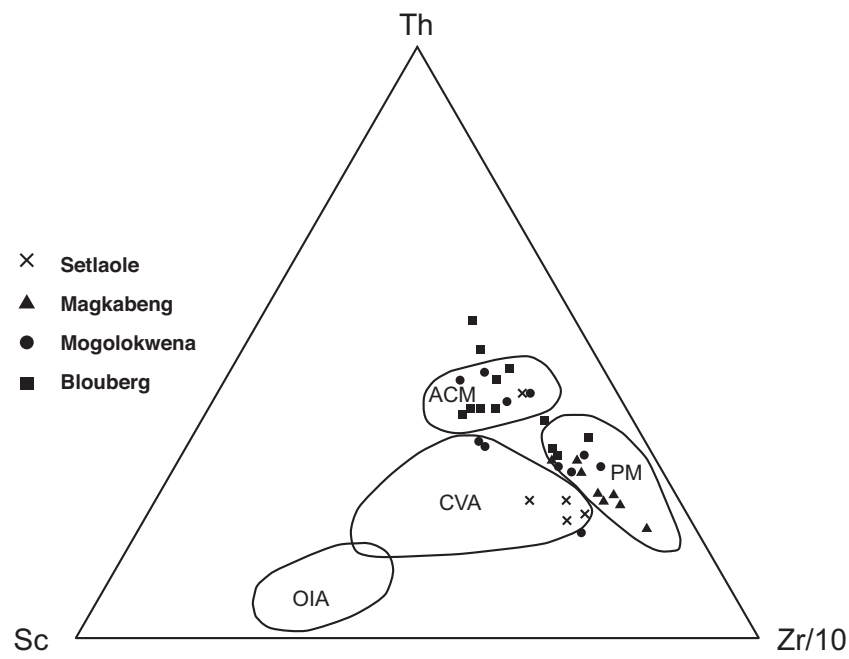

Fig. 9. Tectonic discrimination diagram after Bhatia and Crook (1986). Note that the majority of the samples plot in the active continental margin (ACM) and passive margin (PM) fields, whereas the Setlaole samples mainly plot in the continental volcanic arc (CVA) field. No samples fall into the ocean island basalt (OIB) field.

on the tectonic discrimination diagram (Fig. 9), which is consistent with an enrichment in $\mathrm{Zr}$ relative to Th and Sc, and a high QFR ratio (88:5:7). The results indicate a source composed of quartzrich sandstones that developed along a stable continental shelf. The Makgabeng samples are LREE enriched with $\mathrm{La} / \mathrm{Yb}_{\mathrm{n}}$ ratios ranging from 7.62 to 13.47 (Fig. 10). Combined with an enrichment in $\mathrm{Zr}$, and $\mathrm{Sm} / \mathrm{Yb}_{\mathrm{n}}$ ratios greater than 2 (2.24-3.11), the REE profiles support derivation from a granitic and/or quartzitic source (McLennan et al., 1993). Negative Eu anomalies are consistent with low feldspar percentages in the samples.

\subsection{Mogalakwena Formation}

Nine sandstone and five siltstone samples from the Mogalakwena Formation were analyzed for major and trace elements (Inline Supplementary Tables S1 and S2). Two purple sandstone samples contain 64 and $68 \mathrm{wt} \% \mathrm{SiO}_{2}$, with an average $\mathrm{MgO}$ content of $0.75 \mathrm{wt} \%$. In contrast, one green sandstone sample contains $59 \mathrm{wt} \%$ $\mathrm{SiO}_{2}$ and $3.18 \mathrm{wt} \% \mathrm{MgO}$. The green sandstone is also characterized by much greater abundances of $\mathrm{Cr}, \mathrm{Ni}, \mathrm{Ti}, \mathrm{V}$, and $\mathrm{Zn}$, and a lower $\mathrm{Th} / \mathrm{Sc}$ ratio (1.0) than all other sandstones sampled from the Waterburg Group. Brown sandstones of the Mogalakwena Formation consist of $81-89 \mathrm{wt} \% \mathrm{SiO}_{2}$, which is consistent with the elevated quartz percentages determined from point counting. Unlike the $\mathrm{MgO}$ wt\% contents of the brown sandstones $(<0.04)$, the siltstones contain $0.18-0.3 \mathrm{wt} \% \mathrm{MgO}$, and $58-61 \mathrm{wt} \% \mathrm{SiO}_{2}$. As a whole, the Mogalakwena sandstones and siltstones have an average Ti component of $4098 \mathrm{ppm}$, and an average $\mathrm{Zr}$ composition of $294 \mathrm{ppm}$, which are the highest values in the entire sample suite (Fig. 8a). The average Th/Sc ratio is 2.4. The CIA values for the Mogalakwena samples range from 71 to 89 , which suggests chemical weathering of the source rock. However, the samples plot along a sediment recycling trend on the $\mathrm{Th} / \mathrm{Sc}$ versus $\mathrm{Zr} / \mathrm{Sc}$ graph, indicating zircon addition during multiple sorting and recycling events (Fig. 8b). The samples plot in the passive margin (PM) and active continental margin (ACM) fields, as a result of enrichments in $\mathrm{Th}$ and $\mathrm{Zr}$, elements typically found in the continental crust (Fig. 9; Bhatia and Crook, 1986).

The chondrite-normalized REE patterns produced by seven Mogalakwena samples differ slightly in terms of slope and enrichments/depletions (Fig. 10). All samples are LREE enriched with $\mathrm{La} / \mathrm{Yb}_{n}$ values ranging from 6.03 to 24.20 , but the large range in values, combined with variations in slope, are consistent with a mixed provenance. Samples SA-11-10 and SA-11-27 produce low $\mathrm{Sm} / \mathrm{Yb}_{n}$

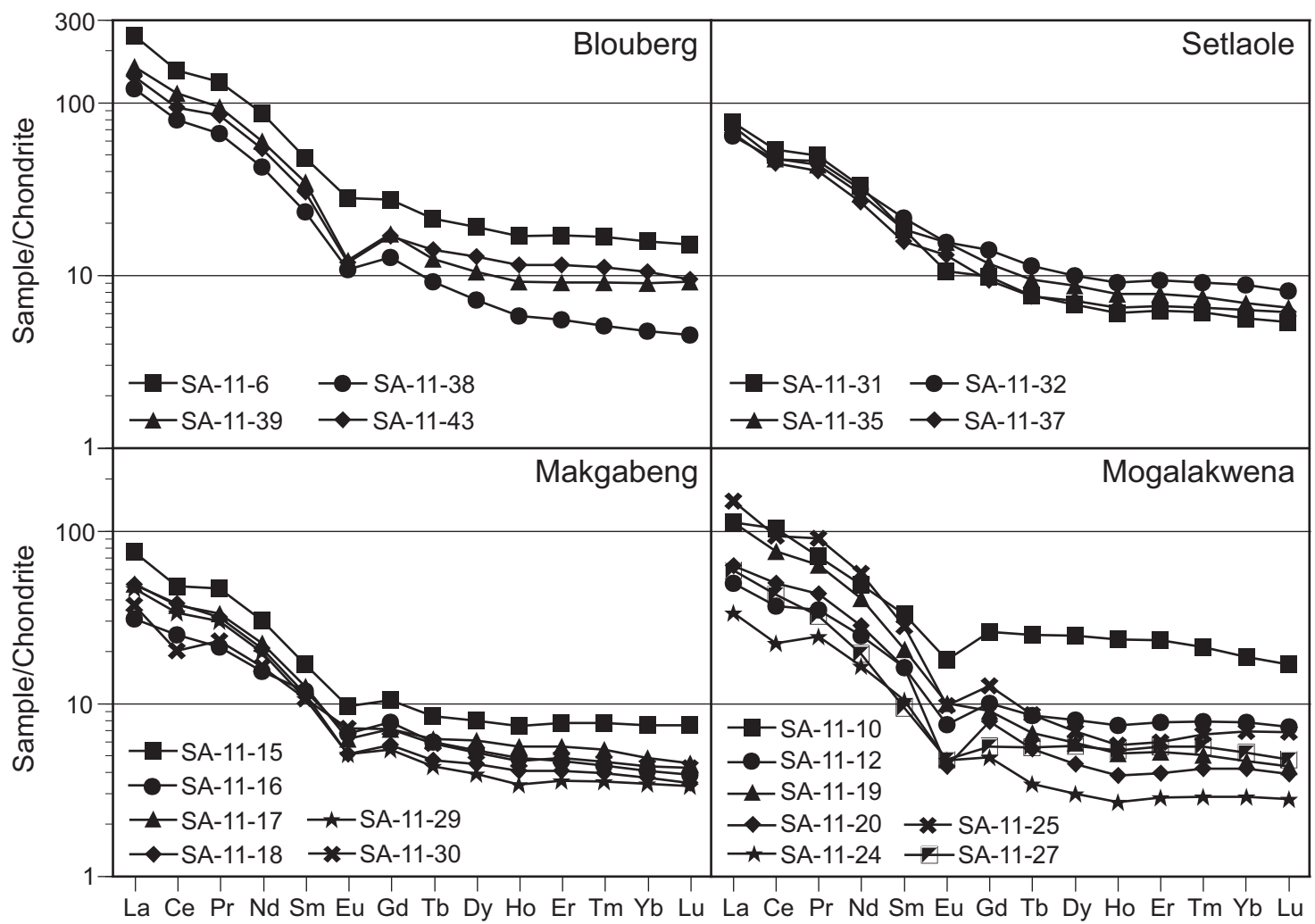

Fig. 10. REE diagrams for the Blouberg, Setlaole, Makgabeng and Mogalakwena formations.

Chondrite normalizing values from Haskin et al. (1968). 
ratios of 1.76 and 1.81 , respectively, whereas all other samples display higher ratios ranging from 2.08 to 4.44 . The higher ratios are similar to those produced by samples from the other three formations and indicate a felsic source, whereas the low $\mathrm{Sm} / \mathrm{Yb}_{n}$ ratios may be more consistent with a mafic source. Negative Eu anomalies produced by all samples reflect the low percentage of feldspar in the rock (QFR ratio of 89:3:8).

\section{U-Pb geochronology}

Uranium-lead ( $\mathrm{U}-\mathrm{Pb})$ age data were determined from detrital zircon in granular sandstone sample SA-11-04, collected from the Blouberg Formation. Sample preparation and analysis were conducted at the Jack Satterly Geochronology Laboratory, University of Toronto. The sample was crushed using a jaw crusher followed by a disk mill. Initial separation of heavy minerals was carried out with a Wilfley table, followed by paramagnetic separations with the Frantz isodynamic separator and density separations using bromoform and methylene iodide. Final sample selection for geochronology was done by hand picking under a microscope, choosing the freshest, least cracked zircon grains. Laser ablation inductively coupled plasma mass spectrometry (LA-ICPMS) was used to obtain age spectra on the detrital zircon population. LA-ICPMS work was done using a VG Series 2 Plasmaquad ICPMS and $213 \mathrm{~nm}$ New Wave laser system. Whole sample grains were mounted on double-sided tape for LA-ICPMS analysis and partially ablated using a $213 \mathrm{~nm}$ laser beam diameter of $10-30 \mu \mathrm{m}$ at $10 \mathrm{~Hz}$ and $70 \%$ power. Data were collected on ${ }^{88} \mathrm{Sr}(10 \mathrm{~ms}),{ }^{206} \mathrm{~Pb}(40 \mathrm{~ms})$, ${ }^{207} \mathrm{~Pb}(40 \mathrm{~ms}),{ }^{232} \mathrm{Th}(10 \mathrm{~ms})$ and ${ }^{238} \mathrm{U}(20 \mathrm{~ms})$. Immediately prior to each analysis, the spot was pre-ablated over a larger area than the beam diameter for about $10 \mathrm{~s}$ to clean the surface and remove surface alteration. Following a 10 s period of baseline accumulation the laser sampling beam was turned on and data were collected for $35 \mathrm{~s}$ followed by a $40 \mathrm{~s}$ washout period. Approximately 250 measurement cycles per sample were produced and ablation pits were about $40 \mu \mathrm{m}$ deep, independent of diameter. In some cases data profiles show unstable emission due to chemical zoning of zircon. Instability was dampened through the use of a $75 \mathrm{ml}$ mixing chamber in-line with the He flow transporting the ablated sample to the plasma. A small amount of monazite was recovered from the 2 Amp/150 magnetic fraction on the Frantz separator. Monazite analyses were performed using reduced laser frequency with the smallest possible spot because of the high $U$ contents. No Th analyses were carried out because Th concentrations of monazite are usually much higher than $U$ and would overload the detector.

Data were edited and reduced using custom VBA software (UTILLAZ program) written by the third author. Generally, only $10 \mathrm{~s}$ of data were used for ${ }^{206} \mathrm{~Pb} /{ }^{238} \mathrm{U}$ ratios because of fractionation caused by hole depth. Most of the ${ }^{207} \mathrm{~Pb} /{ }^{206} \mathrm{~Pb}$ data can be averaged. No corrections were made for common $\mathrm{Pb}$, as this should be negligible in unaltered zircon. ${ }^{88} \mathrm{Sr}$ was monitored in order to detect intersection of the beam with zones of alteration or inclusions, or penetration of the beam through the sample. $\mathrm{Pb}-\mathrm{U}$ data were rejected from areas with excess ${ }^{88} \mathrm{Sr}$ signal. The $\mathrm{Th} / \mathrm{U}$ ratio of the zircon, which can be a useful petrogenetic indicator, was also measured. Zircon from sample DD85-17, a quartz diorite from northern Ontario dated at $3002 \pm 2 \mathrm{Ma}$ (Tomlinson et al., 2003), was used as a standard. Monazite dated at $2690 \pm 1$ Ma from the Ghost Lake batholith in northwest Ontario was used as a standard for that mineral. Sets of 3 sample measurements are bracketed by measurements on standards.

Numerical results of $\mathrm{U}-\mathrm{Pb}$ isotopic analyses by LA-ICPMS are given in Inline Supplementary Table S3. Errors are at one sigma. These reflect reproducibility of individual data profiles and do not include error from sample-standard reproducibility. Concordia

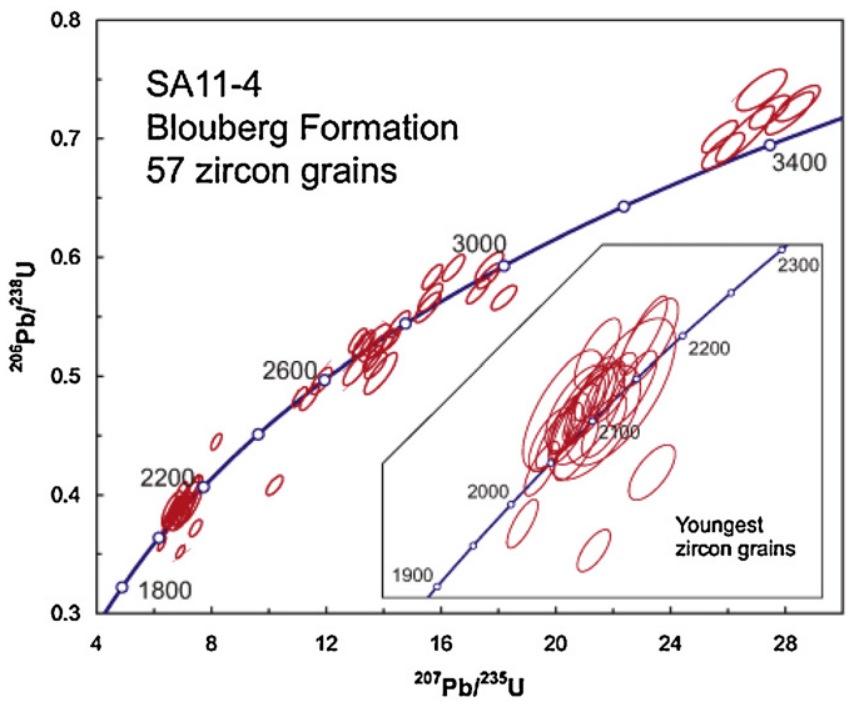

Fig. 11. U-Pb concordia plot showing data on detrital zircon from granular sandstone sample SA-11-04 in the Blouberg Formation, Waterberg Group. The inset shows the youngest data.

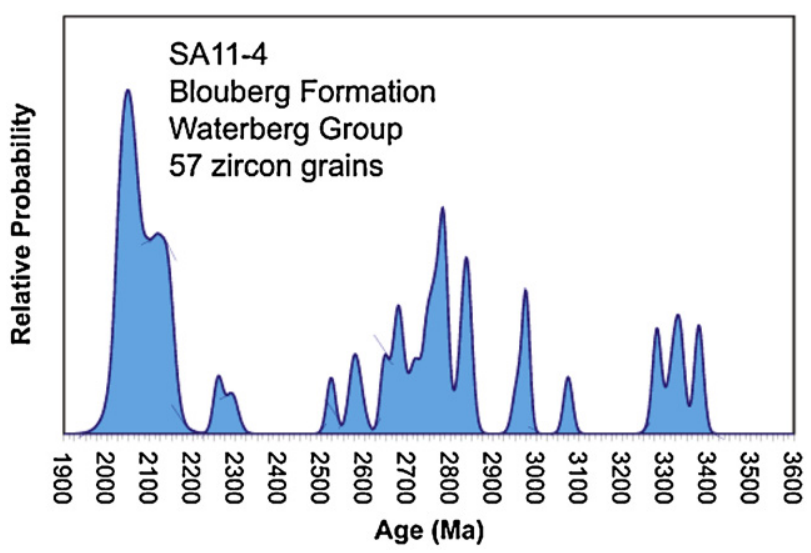

Fig. 12. Age probability density diagram for ${ }^{207} \mathrm{~Pb} /{ }^{206} \mathrm{~Pb}$ ages on 57 detrital zircon grains from granular sandstone sample SA-11-04 of the Blouberg Formation, Waterberg Group.

data for zircon are plotted in Fig. 11 using the Isoplot program of Ludwig $(1998,2003)$. Error ellipses and regression errors are given at $95 \%$ confidence levels. A probability density distribution for near-concordant ${ }^{207} \mathrm{~Pb} /{ }^{206} \mathrm{~Pb}$ ages is shown in Fig. 12 using the AgeDisplay program written by K. Sircombe. Results show a significant spread of zircon ages with numerous peaks at the following ages (in Ma):

\begin{tabular}{llll}
\hline 2049 & 2119 & 2261 & 2289 \\
2523 & 2578 & 2649 & 2679 \\
2720 & 2782 & 2837 & 2975 \\
3074 & 3281 & 3330 & 3379 \\
\hline
\end{tabular}

The youngest peak at $2043 \pm 8 \mathrm{Ma}$ (defined by the 10 youngest data with MSWD - 0.8) is also the largest and defines a maximum age for deposition of the Blouberg Formation. A considerable proportion of the detrital zircon is Paleoproterozoic, including a small peak of 2100-2200 Ma Eburnean aged material. The rest stretches from late Neoarchean to Mesoarchean.

Nine monazite crystals were also dated. Two of these gave Archean ages. Grain $3 \mathrm{~m}$ (Inline Supplementary Table S3) appears to have a Mesoarchean monazite core overgrown by Paleoproterozoic monazite. Two Paleoproterozoic monazite grains have very low $\mathrm{U}$ concentrations and therefore relatively imprecise ages. The five 


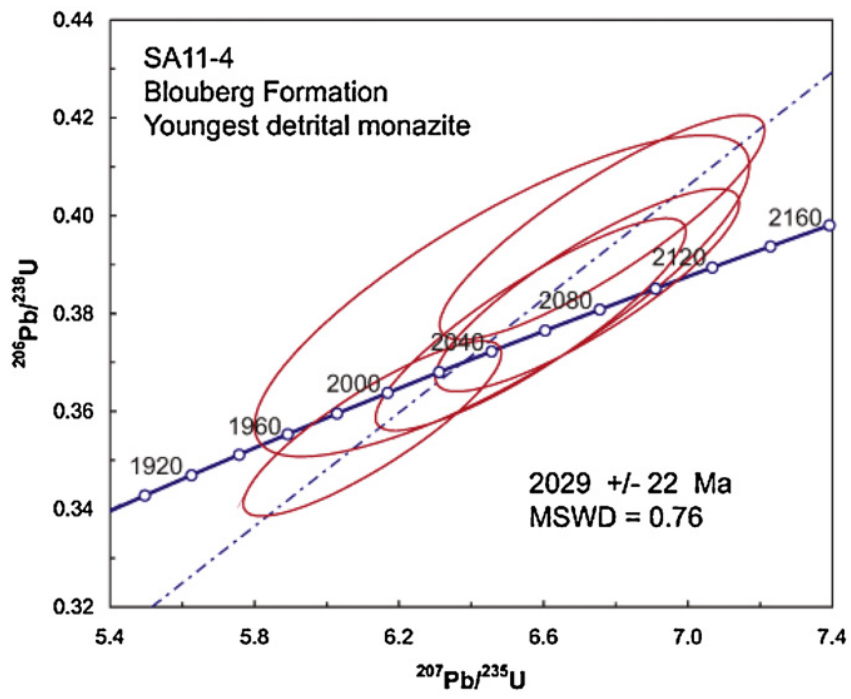

Fig. 13. U-Pb concordia plot showing data on the youngest detrital monazite grains from granular sandstone sample SA-11-04 in the Blouberg Formation, Waterberg Group.

remaining grains are Paleoproterozoic and overlap with an average of $2029 \pm 22$ Ma (MSWD - 0.8, Fig. 13).

Inline Supplementary Table S3 can be found online at http://dx.doi.org/10.1016/j.precamres.2012.12.009.

\section{Discussion}

Preserved formation margins of the Waterberg Group indicate that with time, deposition encroached northwards, eventually onlapping the southern strand of the Melinda Fault (Fig. 4c). This implies that a topographic high established over the Central Zone of the Limpopo Belt was gradually being peneplaned throughout Waterberg Group deposition. This model is supported by fluvial paleocurrent directions to the south (Setlaole and Makgabeng formations) and southeast (Mogalakwena Formation), and suggests a relatively local $\mathrm{CZ}$ provenance.

\subsection{Significance of sandstone petrography}

The Blouberg, Setlaole, Makgabeng, and Mogalakwena formations are composed mainly of conglomerate and medium-grained to granular sandstones. Minor thin-bedded siltstone separates fining-upward cycles in the Mogalakwena Formation, but other fine-grained deposits are relatively rare. The sandstones contain abundant quartz (70-89\% relative to feldspar and lithic fragments), which suggests a silicic-dominated provenance consistent with felsic intrusive or extrusive, and/or sedimentary source rocks. Predominant clasts of silicic gneiss, quartz arenite and chert in conglomerates further corroborate a felsic-dominated source. Low overall Qp/Q ratios ranging from $0.04-0.16$ (Table 1 ) are generally considered to be consistent with greater transport distances and mature sedimentary deposits (Johnsson, 1993; Heins, 1995), but the Blouberg, Setlaole and Mogalakwena strata are texturally submature, as well as mineralogically submature, as indicated by the overall proportion of lithic fragments. This suggests that the abundant monocrystalline quartz in the Waterberg strata is probably multicycle in origin, having been sourced mainly from older sedimentary rocks (c.f. Blatt and Christie, 1963). A sedimentary-dominated provenance is also supported by the composition of the lithic fragments within the sandstones, wherein $>90 \%$ are sedimentary. In addition, all samples from the Waterberg Group plot in the recycled orogenic provenance on the QFL diagram
(Fig. 7b), for which folded and faulted sedimentary and metasedimentary rocks are generally considered sources (Dickinson and Suczek, 1979). Therefore, the petrographic results are consistent with a sedimentary-dominated provenance, such as the quartz-rich shelfal deposits of the Mesoarchean Beit Bridge Complex (Kröner et al., 1999) in the CZ of the Limpopo Belt. Detrital zircon U-Pb ages from sedimentary rocks of the Beit Bridge deposits range from ca. 3.71 to 3.25 Ga (Barton and Sergeev, 1997; Kröner et al., 1998), which overlap the oldest ages determined from our study (3281 Ma, $3330 \mathrm{Ma}, 3379 \mathrm{Ma}$ ). In addition, paleocurrent directions to the $\mathrm{W}$ and SSW as determined from Bumby (2001) strongly support a source to the north and northeast of the study area, consistent with the location of the Beit Bridge Complex. The Waterberg formations also received some detrital input from other rock types, as indicated by minor lithic volcanic and gneiss fragments in most formations. A detrital zircon age peak of 2578 Ma produced by the Blouberg sample is consistent with the age of the Singelele gneiss (Jaeckel et al., 1997), and may coincide with a high grade metamorphic event that occurred at ca. 2570 Ma (Holzer et al., 1998). The age peak at 2649 Ma may be correlated with ages of ca. $2.65 \mathrm{Ga}$ and $2.62 \mathrm{Ga}$ determined from two compositional varieties of the Verbaard gneiss (Jaeckel et al., 1997). Many additional U-Pb ages produced by detrital zircons in the Blouberg sample are previously unreported in the literature, and their wide age range may indicate a gradual terrane accretion model for the Limpopo orogeny.

\subsection{Significance of sandstone and siltstone geochemistry}

Geochemical results from the studied Waterberg formations indicate an overall similarity in chemical composition of the samples, but key distinctions between formations support a mixed provenance. Overall high abundances of $\mathrm{SiO}_{2}$ are commensurate with elevated quartz percentages as detrital grains, and silica cement has augmented these values in the Makgabeng and Mogalakwena formations. The relatively high quartz and $\mathrm{SiO}_{2}$ components are atypical of tectonically controlled sedimentary basins where sediment residence times are generally low. Silica enrichment in the Makgabeng Formation can be attributed to the enhanced sorting process by wind in an aeolian depositional environment, but the Mogalakwena and Blouberg formations are interpreted to have formed in fluvial environments. This discrepancy can be explained by multiple recycling episodes, which selectively remove labile feldspars and clays, leaving a sedimentary deposit rich in quartz and stable heavy minerals such as zircon and monazite. The presence of these minerals is suggested by enrichments in $\mathrm{Zr}$, and the light and middle REE relative to the heavy REE. All Waterberg samples plot along the sediment recycling trend on the $\mathrm{Th} / \mathrm{Sc}$ versus $\mathrm{Zr} / \mathrm{Sc}$ diagram (Fig. 8b), supporting the addition of zircon with successive recycling. The quartz arenite succession of the Beit Bridge Complex could have received recycled and/or chemically weathered detritus that once deposited, would have been reworked and efficiently sorted along a shoreline on a stable continental shelf. A passive margin provenance for some of the Waterberg samples is supported by the tectonic discrimination diagram in which all Makgabeng, and some Blouberg, Setlaole, and Mogalakwena samples plot (Fig. 9).

Although the majority of the Waterberg samples reflect a felsicdominated provenance with average $\mathrm{Ti} / \mathrm{Zr}$ ratios of 9 (Blouberg), 6 (Setlaole), and 5 (Makgabeng), the Mogalakwena Formation is relatively enriched in $\mathrm{Ti}$ (average $\mathrm{Ti} / \mathrm{Zr}$ ratio of 14) (Fig. 8a). This discrepancy can be attributed to the inclusion of purple and green sandstones in the sample suite, which produced a low $\mathrm{Th} / \mathrm{Sc}$ ratio (1.0), relatively high MgO contents, and large abundances of $\mathrm{Cr}$ and $\mathrm{Ni}$, all of which indicate a mafic source component. Similarly, green sandstone sampled from the Blouberg Formation has elevated $\mathrm{MgO}, \mathrm{Cr}, \mathrm{Ni}$ and Ti contents (Inline Supplementary Tables S1 


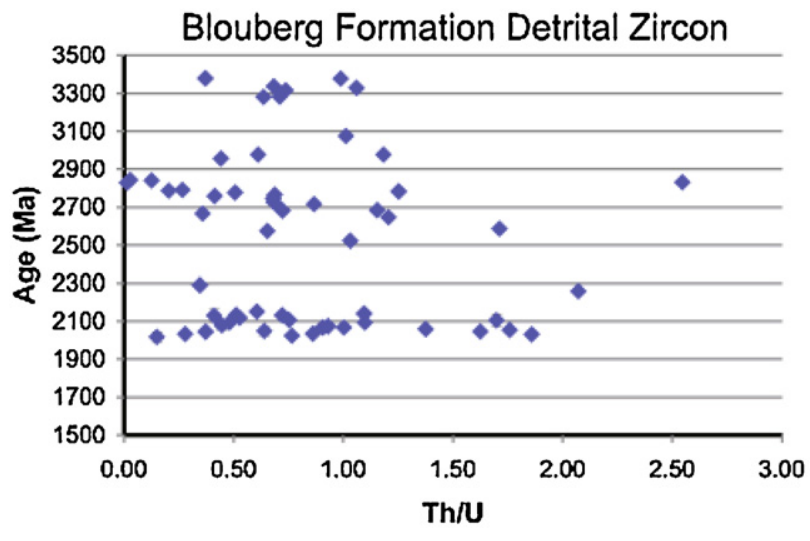

Fig. 14. ${ }^{207} \mathrm{~Pb} /{ }^{206} \mathrm{~Pb}$ ages versus $\mathrm{Th} / \mathrm{U}$ ratios on 57 detrital zircon grains from the Blouberg Formation.

and S2). Therefore, the bulk of the Waterberg samples are consistent with a siliceous provenance, but mafic rocks also contributed some detritus to the basins. Considering that all rocks in the Limpopo Belt have been subjected to high-grade metamorphism, mafic rock-forming minerals such as pyroxene and hornblende would have been altered to chlorite and epidote, which are both heavy minerals with densities $>2.9$. Heavy minerals are typically deposited as lags on erosional surfaces or along the stoss sides of ripples and dunes where flow velocity is greatest. This results in heavy mineral-rich laminae between bedforms or on dune surfaces, examples of which were identified in the Blouberg and Mogalakwena formations as purple and green sandstone and siltstone. These laminae and beds contain abundant chlorite and opaque minerals.

\subsection{Significance of $\mathrm{U}-\mathrm{Pb}$ detrital geochronology}

The petrographic and geochemical results point toward derivation of the Waterberg sedimentary deposits from the Limpopo Belt. Therefore, the geochronology data suggest that it was continually active down to approximately $2046 \mathrm{Ma}$, or that the ca. 2.04 tectono-metamorphic event uplifted a considerable range of Limpopo source rocks with various ages. The wide array of $\mathrm{U}-\mathrm{Pb}$ detrital zircon ages encompasses the three main age clusters in the Limpopo Belt as determined by numerous workers (ca. 3.3-3.1 Ga, ca. 2.7-2.5 Ga, ca. 2.0 Ga). The middle Archean ages are typical of the $\mathrm{CZ}$ and $\mathrm{SMZ}$, the late Archean ages have been recorded in all three zones, and the Paleoproterozoic ages are well represented in the CZ and NMZ, but not in the SMZ (Kramers and Mouri, 2011). Therefore, geochronological and sedimentological data support a CZ-dominated provenance for the Waterberg strata. The Waterberg Group thus could have received detritus from rock units of varying composition and age in the $\mathrm{CZ}$, which include ca. $2.0 \mathrm{Ga}$ igneous and minor sedimentary rocks of the Mahalapye Complex (McCourt and Armstrong, 1998), gneisses and igneous rocks of the Archean Phikwe Complex, and Archean sandstone, shale, carbonate, chert, banded iron formation and volcanic rocks of the Beit Bridge Complex (Light, 1982; van Reenen et al., 1992). A plot of Th/U ratios versus ${ }^{207} \mathrm{~Pb} /{ }^{206} \mathrm{~Pb}$ ages (Fig. 14) shows a normal range for magmatic zircon (ca. 0.1-1.0) for most of the zircon except for unusually high values on Paleoprotoerozoic and Neoarchean rocks and low $(<0.1)$ values for ca. $2.85 \mathrm{Ga}$ rocks. Low values are typical of metamorphic zircon. This suggests that the $2.85 \mathrm{Ga}$ event represented a major orogeny that resulted in burial metamorphism. Most of the monazite is from $2.0 \mathrm{Ga}$ rocks. This might in part be due to the fact that monazite is a relatively soft mineral that is unlikely to survive multiple sedimentary cycles. Monazite is usually found as a magmatic mineral in S-type granites as well as in metamorphic rocks, where it sometimes shows relatively low $U$ (as with grains $3 \mathrm{~m}, 4 \mathrm{~m}$ and $7 \mathrm{~m}$ ) and Th/U ratios (Davis et al., 1994). This suggests that the latest detrital peak at ca. $2.0 \mathrm{Ga}$ represents a significant tectonic event that resulted in crustal melting and regional metamorphism.

\section{Conclusions}

The Waterberg Group in the study area is composed of three formations that developed in braided fluvial settings, and one formation that was deposited in a mixed braided stream and aeolian-dominated environment. The coarse clastic sedimentary detritus was deposited during two phases, which include: (1) pullapart basin development along the trace of the Melinda Fault Zone, with syntectonic deposition of the Blouberg strata, and (2) deposition of the Setlaole, Makgabeng and Mogalakwena formations over the Limpopo mountains that were formed during earlier deformation of the Blouberg strata. Detailed petrography, major and trace element geochemistry, and detrital zircon $\mathrm{U}-\mathrm{Pb}$ geochronology enable a clearer understanding of the provenance of the Waterberg Group, and provide possible clues regarding the termination of the Limpopo orogenic event.

Point counts determined from Waterberg Group samples indicate that the majority of the detritus was derived from sedimentary and silicic gneiss source terranes. The abundance of quartz relative to feldspar and rock fragments in all formations is consistent with a felsic-dominated provenance, and the predominance of chert and arenite rock fragments supports an older sedimentary source. Major and trace element geochemical results display a very high $\mathrm{SiO}_{2}$ component in all samples, as well as enrichments in Th and especially Zr. Locally abundant chlorite in sandstone and siltstone between bedsets and dune structures indicates a minor mafic volcanic source component. The mafic source is also indicated by geochemical results from local green and purple sandstones, siltstones and sandstone interbeds in conglomerate, which produced low $\mathrm{SiO}_{2}$ wt percentages and associated high $\mathrm{MgO}, \mathrm{Ti}, \mathrm{Ni}$ and $\mathrm{Cr}$ values. The Setlaole samples contain slightly more plagioclase feldspar than the other formations, and plot in the continental volcanic arc field on the tectonic discrimination diagram, which contrasts with the Blouberg, Makgabeng and Mogalakwena samples, which plot in the active continental margin and passive margin fields. This, combined with a lack of deformation, suggests that the Setlaole Formation is unlikely to be correlative with the Blouberg Formation. Light REE enriched patterns produced by all Waterberg samples support a felsic-dominated source and $\mathrm{Sm} / \mathrm{Yb}_{\mathrm{n}}$ ratios greater than 2 reflect monazite in the source.

Detrital zircon $\mathrm{U}-\mathrm{Pb}$ age data display peaks at various dates ranging from 3379 to $2046 \mathrm{Ma}$. Peaks at $3281 \mathrm{Ma}, 3330 \mathrm{Ma}$, and 3379 Ma coincide with ages determined from the Beit Bridge Complex, which is composed of a continental platform assemblage dominated by siliceous sedimentary deposits and mafic volcanic units (Boryta and Condie, 1990). Additional peaks at $2578 \mathrm{Ma}$ and 2649 Ma can be correlated with ages determined from the Limpopo CZ Singelele gneiss and Verbaard gneiss, respectively. The largest peak at $2046 \mathrm{Ma}$ is the youngest, and coincides with the timing of an inferred tectono-metamorphic event at ca. 2.0, and probably represents the termination of the Limpopo orogenic event. Overall, the paleocurrent, geochemical, petrographic and geochronological data are commensurate with derivation of detritus from the Archean Beit Bridge Complex, with secondary input from Paleoproterozoic granitic gneisses. Further detailed analysis of the numerous detrital zircon ages in our investigation could lead to a better understanding of the timing of thermal and tectonic events that occurred during the Limpopo orogeny. 


\section{Acknowledgments}

This project would not have been possible without a University of Western Ontario Academic Development Fund grant awarded to the first author. We would also like to thank the National Research Foundation of South Africa for providing funding for logistical support. Many thanks to Rick Balgobin and Steve Wood who prepared the samples for thin sections and geochemistry. Incisive reviews by Editor Peter Cawood and an anonymous reviewer significantly improved the manuscript.

\section{References}

Barton Jr., J.M., Klemd, R., Zeh, A., 2006. The Limpopo Belt: a result of Archaean to Proterozoic Turkic-type orogenesis? In: Reimold, W.U., Gibson, R.L. (Eds.), Processes on the Early Earth. , pp. 315-332, Geological Society of America Special Paper 405.

Barton Jr., J.M., Sergeev, S., 1997. High precision, U-Pb analyses of single grains of zircon from quartzite in the Beit Bridge Group yield a discordia. South African Journal of Geology 100, 37-41.

Best, J., Bridge, J., 1992. The morphology and dynamics of low amplitude bedwaves upon upper stage plane beds and the preservation of planar laminae. Sedimentology 39, 737-752.

Bhatia, M.R., Crook, K.A.W., 1986. Trace element characteristics of graywackes and tectonic setting discrimination of sedimentary basins. Contributions to Mineralogy and Petrology 92, 181-193.

Blatt, H., Christie, J.M., 1963. Undulatory extinction in quartz of igneous and metamorphic rocks and its significance in provenance studies of sedimentary rocks. Journal of Sedimentary Petrology 33, 559-579.

Boryta, M., Condie, K.C., 1990. Geochemistry and origin of the Archaean Beit Bridge Complex, Limpopo Belt, South Africa. Journal of the Geological Society 147, 229-239.

Bumby, A.J., 2001. The geology of the Blouberg Formation, Waterberg and Soutpansberg groups in the area of Blouberg Mountain, Northern Province, South Africa. Ph.D. Thesis, University of Pretoria, Pretoria, South Africa.

Bumby, A.J., Eriksson, P.G., van der Merwe, R., 2004. The Early Proterozoic sedimentary record in the Blouberg area, Limpopo Province, South Africa; implications for the timing of the Limpopo orogenic event. Journal of African Earth Sciences 39, 123-131.

Bumby, A.J., Eriksson, P.G., van der Merwe, R., Brümer, J.J., 2001a. Shear-zone controlled basins in the Blouberg area, Northern Province, South Africa: syn- and post-tectonic sedimentation relating to c. $2.0 \mathrm{Ga}$ reactivation of the Limpopo Belt. Journal of African Earth Sciences 33, 445-461.

Bumby, A.J., Eriksson, P.G., van der Merwe, R., Maier, W., 2001b. The stratigraphic relationship between the Waterberg Group and the Soutpansberg Group (Northern Province, South Africa): evidence from the Blouberg area. South African Journal of Geology 104, 205-216.

Bumby, A.J., Eriksson, P.G., van der Merwe, R., Steyn, G.L., 2002. A half-graben setting for the Proterozoic Soutpansberg Group (South Africa): evidence from the Blouberg area. Sedimentary Geology 147, 37-56.

Cant, D.J., Walker, R.G., 1976. Development of a braided facies fluvial model for the Devonian Battery Point Sandstone, Quebec. Canadian Journal of Earth Sciences 13, 102-119.

Collinson, J.D., 1996. Alluvial sediments. In: Reading, H.G. (Ed.), Sedimentary Environments: Processes, Facies and Stratigraphy. Blackwell Science, Oxford, pp. 37-82.

Corcoran, P.L., Mueller, W.U., Padgham, W., 1999. Influence of tectonism and climate on lithofacies distribution and sandstone and conglomerate composition in the Archean Beaulieu Rapids Formation, Northwest Territories, Canada. Precambrian Research 94, 175-204.

Davis, D.W., Schandl, E.S., Wasteneys, H.A., 1994. U-Pb dating of minerals in alteration halos of Superior Province massive sulfide deposits: syngenesis vs. metamorphism. Contributions to Mineralogy and Petrology 115, 427-437.

Dickinson, W.R., Suczek, C.A., 1979. Plate tectonics and sandstone compositions. American Association of Petroleum Geologists Bulletin 63, 2164-2182.

Dickinson, W.R., Beard, L.S., Brakenridge, G.R., Erjavec, J.L., Ferguson, R.C., Inman, K.F., Knepp, R.A., Lindberg, F.A., Ryberg, P.T., 1983. Provenance of North American Phanerozoic sandstones in relation to tectonic setting. Geological Society of America Bulletin 94, 222-235.

Dorland, H.C., Beukes, N.J., Gutzmer, J., Evans, D.A.D., Armstrong, R.A., 2006. Precise SHRIMP U-Pb zircon age constraints on the lower Waterberg and Soutpansberg Groups, South Africa. South African Journal of Geology 109, 139-156.

Eriksson, K.A., 1978. Alluvial and destructive beach facies from the Archaean Moodies Group, Barberton Mountain Land, South Africa and Swaziland. In: Miall, A.D. (Ed.), Fluvial Sedimentology. Canadian Society of Petroleum Geologists Memoir 5. pp. 287-311.

Eriksson, P.G., Simpson, E.L., Eriksson, K.A., Bumby, A.J., Steyn, G.L., 2000. Muddy rollup structures in siliciclastic interdune beds of the c. $1.8 \mathrm{Ga}$ Waterberg Group, South Africa. Palaios 15, 177-183.

Eriksson, P.G., Bumby, A.J., Brumer, J.J., van der Neut, M., 2006. Precambrian fluvial deposits; enigmatic palaeohydrological data from the c. 2-1.9 Ga Waterberg Group, South Africa. Sedimentary Geology 190, 25-46.
Folk, R.L., Andrews, P.B., Lewis, D.W., 1970. Detrital sedimentary rock classification and nomenclature for use in New Zealand. New Zealand Journal of Geology and Geophysics 13, 937-968.

Hanson, R.E., Gose, W.A., Crowley, J.L., Ramezani, J., Bowring, S.A., Bullen, D.S., Hall, R.P., Pancake, J.A., Mukwakwami, J., 2004. Paleoproterozoic intraplate magmatism and basin development on the Kaapvaal Craton: Age, paleomagnetism and geochemistry of $\sim 1.93$ to $\sim 1.87 \mathrm{Ga}$ post-Waterberg dolerites. South African Journal of Geology 107, 233-254.

Haskin, L.A., Haskin, M.A., Frey, F.A., Wildman, T.R., 1968. Relative and absolute terrestrial abundances of the rare earths. In: Ahrens, L.H. (Ed.), Origin and Distribution of the Elements. Pergamon, Oxford, pp. 889-911.

Heins, W.A., 1995. The use of mineral interfaces in sand-sized rock fragments to infer ancient climate. Geological Society of America Bulletin 107, 113-125.

Holzer, L., Frei, R., Barton Jr., J.M., Kramers, J.D., 1998. Unravelling the record of successive high grade events in the Central Zone of the Limpopo belt using $\mathrm{Pb}$ single phase dating of metamorphic minerals. Precambrian Research 87, 87-115.

Hunter, R.E., 1977. Basic types of stratification in small Aeolian dunes. Sedimentology 24, 361-387.

Hunter, R.E., 1981. Stratification styles in eolian sandstones: some Pennsylvanian to Jurassic examples from the western interior U.S.A. In: Etheridge, F.G, Flores, R.M. (Eds.), Recent and Ancient Nonmarine Depositional Environments: Models for Exploration: SEPM Special Publication 31. , pp. 315-329.

Jaeckel, P., Kroener, A., Kamo, S.L., Brandl, G., Wendt, J.I., 1997. Late Archaean to early Proterozoic granitoid magmatism and high-grade metamorphism in the central Limpopo Belt, South Africa. Journal of the Geological Society of London $154,25-44$

Johnsson, M.J., 1993. The system controlling the composition of clastic sediments. In: Johnsson, M.J., Basu, A. (Eds.), Processes Controlling the Composition of Clastic Sediments. Geological Society of America Special Paper 284. , pp. 1-19.

Kamber, B.S., Kramers, J.D., Napier, R., Cliff, R.A., Rollinson, H.R., 1995. The triangle shear zone, Zimbabwe, revisited; new data document an important date at $2.0 \mathrm{Ga}$ in the Limpopo Belt. Precambrian Research 70, 191-213.

Kocurek, G., Dott Jr., R.H., 1981. Distinction and uses of stratification type in the interpretation of eolian sand. Journal of Sedimentary Petrology 51, 579-595.

Kramers, J.D., Mouri, H., 2011. The geochronology of the Limpopo Complex; a controversy solved. Geological Society of America Memoir 207, 85-106.

Kröner, A., Jaeckel, P., Brandl, G., Nechin, A.A., Pidgeon, R.T., 1999. Single zircon ages for granitoid gneisses in the Central Zone of the Limpopo Belt, southern Africa and geodynamic significance. Precambrian Research 93, 299-337.

Kröner, A., Jaeckel, P., Hofmann, A., Nemchin, A.A., Brandl, G., 1998. Field relationships and age of supracrustal Beit Bridge Complex and associated granitoid gneisses in the Central Zone of the Limpopo Belt, South Africa. South African Journal of Geology 101, 201-213.

Light, M.P.R., 1982. The Limpopo mobile belt; a result of continental collision. Tectonics $1,325-342$.

Long, D.G.F., 2011. Architecture and depositional style of fluvial systems before land plants: a comparison of Precambrian, Early Paleozoic, and modern river deposits. SEPM Special Publication 97, pp. 37-61.

Longerich, H.P., Jenner, G.A., Fryer, B.J., Jackson, S.E., 1990. Inductively coupled plasma-mass spectrometric analysis of geological samples: a critical evaluation based on case studies. Chemical Geology 83, 105-118.

Loope, D.B., Mason, J.A., Dingus, L., 1999. Lethal landslides from Aeolian dunes. Journal of Geology 107, 707-713.

Ludwig, K.R., 1998. On the treatment of concordant uranium-lead ages. Geochimica et Cosmochimica Acta 62, 665-676.

Ludwig, K.R., 2003. User's Manual for Isoplot 3.00 a Geochronological Toolkit for Excel. Berkeley Geochronological Center Special Publication 4, 71 pp.

Mack, G.H., Rasmussen, K.A., 1984. Alluvial-fan sedimentation of the Cutler Formation (Permo-Pennsylvanian) near Gateway, Colorado. Geological Society of America Bulletin 95, 109-116.

McCourt, S., Armstrong, R.A., 1998. SHRIMP U-Pb zircon chronology of granites from the Central Zone, Limpopo Belt, southern Africa: Implications for the age of the Limpopo Orogeny. South African Journal of Geology 101, 329-337.

McKee, E.D., 1979. Ancient sandstones considered to be Eolian. In: McKee, E.D. (Ed.), A Study of Global Sand Seas: U.S. Geological Survey Professional Paper 1052. , pp. 187-238.

McLennan, S.M., Hemming, S., McDaniel, D.K., Hanson, G.N., 1993. Geochemical approaches to sedimentation, provenance, and tectonics. In: Johnsson, M.J., Basu, A. (Eds.), Processes Controlling the Composition of Clastic Sediments. Geological Society of America Special Paper 284. , pp. 21-40.

McLennan, S.M., Taylor, S.R., 1991. Sedimentary rocks and crustal evolution; tectonic setting and secular trends. Journal of Geology 99, 1-21.

Miall, A.D., 1978. Lithofacies types and vertical profile models in braided river deposits: a summary. In: Miall, A.D. (Ed.), Fluvial Sedimentology. Canadian Society of Petroleum Geologists Memoir 5. , pp. 597-604.

Miall, A.D., 1992. Alluvial deposits. In: Walker, R.G., James, N.P. (Eds.), Facies Models: Response to Sea Level Change. Geological Association of Canada, pp. 119-142.

Mueller, W., Donaldson, J.A., Doucet, P., 1994. Volcanic and tectono-plutonic influences on sedimentation in the Archean Kirkland Basin Abitibi greenstone belt, Canada. Precambrian Research 68, 201-230.

Nesbitt, H.W., Young, G.M., 1982. Early Proterozoic climates and plate motions inferred from major element chemistry of lutites. Nature 299, 715-717.

Roering, C., van Reenen, D.D., Smit, C.A., Barton Jr., J.M., De Beer, J.H., De Wit, M.J., Stettler, E.H., Van Schalkwyk, J.F., Stevens, G., Pretorius, S., 1992. Tectonic 
model for the evolution of the Limpopo Mobile belt. Precambrian Research 55, 539-552.

Rollinson, H.R., 1993. A terrane interpretation of the Archaean Limpopo belt. Geology Magazine 130, 755-765.

Schaller, M., Steiner, O., Studer, I., Holzer, L., Herwegh, M., Kramers, J.D., 1999. Exhumation of Limpopo Central Zone granulites and dextral continent-scale transcurrent movement at $2.0 \mathrm{Ga}$ along the Palala Shear Zone, Northern Province, South Africa. Precambrian Research 96, 263-288.

Simpson, E.L., Eriksson, K.A., Kuklis, C.A., Eriksson, P.G., Bumby, A.J., 2004. Saline pan deposits from the approximately $1.8 \mathrm{Ga}$ Makgabeng Formation, Waterberg Group, South Africa. Sedimentary Geology 163, 279-292.
Taylor, S.R., McLennan, S.M., 1985. The Continental Crust: Its Composition and Evolution. Blackwell, Oxford, $312 \mathrm{pp}$.

Tomlinson, K.Y., Davis, D.W., Stone, D., Hart, T.R., 2003. U-Pb age and Nd isotopic evidence for crustal recycling and Archean terrane development in the south-central Wabigoon subprovince, Canada. Contributions to Mineralogy and Petrology 144, 684-702.

Treloar, P.J., Coward, M.P., Harris, N.B.W., 1992. Himalayan-Tibetan analogies for the evolution of the Zimbabwe craton and Limpopo Belt. Precambrian Research 55 571-587.

van Reenen, D.D., Roering, C., Ashwal, L.D., de Wit, M.J., 1992. Regional geological setting of the Limpopo Belt. Precambrian Research 55, 1-5. 